\title{
CANADIAN ENVIRONMENTAL NON-GOVERNMENTAL ORGANIZATIONS' POSITIONS REGARDING NUCLEAR POWER IN ONTARIO
}

\author{
by \\ Jay P.D. Wilson \\ Honours Environmental Science, Bachelor of Science \\ University of Guelph, 2006 \\ A thesis presented to Ryerson University \\ In partial fulfillment of the \\ Requirements for the degree of \\ Master of Applied Science \\ In the Program of \\ Environmental Applied Science and Management
}

Toronto, Ontario, Canada, 2010

CJay P.D. Wilson, 2010 


\section{AUTHOR'S DECLARATION:}

I hereby declare that I am the sole author of this thesis.

I authorize Ryerson University to lend this thesis to other institutions or individuals for the purpose of scholarly research.

I further authorize Ryerson University to reproduce this thesis by photocopying or other means, in total or in part, at the request of other institutions or individuals for the purpose of scholarly research. 


\section{Acknowledgements:}

The author would like to acknowledge all of the people who at different times and in different ways helped to bring this thesis out of our collective imaginations and into the real world. This work, however important is not expected to be a bestseller and it is likely that if you are reading this you had some part to play in its inception, execution and completion.

So to my family and friends and my partner Chelsey who put up with late nights and cancelled plans, my thesis advisor who provided constant support in every aspect of my degree and my thesis committee who were generous with their input and their time and who were always willing to meet with me on short notice: thank you all.

While technically there will eventually be only one person crossing the stage to receive a diploma for this work, it belongs to all of us. 


\section{TABLE OF CONTENTS:}

AUTHOR'S DECLARATION:

ACKNOWLEDGEMENTS:

ABSTRACT:

1-0: INTRODUCTION

1-1: Purpose

3

2-0: BACKGROUND

4

2-1: Cumate Change

4

2-2: Cimate Change in the Public Eve

2-3: The Canadian Government's Climate Change Plan

2-4: The Ontario Government's Cumate Change action Plan

2-5: Ontario's Integrated Power System PLan (IPSP)

2-7: THE NUCLEar Renaissance

2-8: Types of Power Generation in Ontario

2-9: Non-Governmental Organizations (NGOS) In Canada

2-10: Historical Role of ENGOS in AfFecting NuClear Poulcy

2-11: Changes in ENGo Policy Influence

2-12: NGOS and Non-State Market Driven (NSMD) Mechanisms

2-13: NGOS AND AGENDA SETting

2-14: The Nature of Siting Conflicts

2-15: THEORETICAL EXERCISE OF POWER 
4-1: DEFINITION OF AN ENGO 35

4-2: Selecting Potential Participant Engos 36

4-3: QUESTIONNAIRE - KI RECRUITMENT 38

4-4: QUESTIONNAIRE - THE INTERVIEW 40

4-5: QUESTIONNAIRE - ANALYSIS OF THE TRANSCRIPTIONS 42

4-6: TEXTS - ENGO SELECTION 43

4-7: TEXTS - SELECTION OF TEXTS 45

4-8: TEXTS - TEXT ANALYSIS 47

5-0: RESULTS 50

5-1: INTERVIEW RESULTS 50

5-2: TEXT ANALYSIS RESULTS 60

6-0: CONCLUSION 66

7-0: DISCUSSION 70

8-0: IMPLICATIONS 75

9-0: REFERENCES

Interview Guide 3 


\section{LIST OF TABLES:}

TABLE 1: ENGOS THAT HAD POTENTIAL KIS CONTACTED FOR INTERVIEWS WHO AGREED TO PARTICIPATE

TABLE 2: LIST OF ANALYZED TEXTS

TABLE 3: ANALYSIS OF ENERGY PROBE'S FOUR TEXTS

TABLE 4: TEXT ANALYSIS RESULTS FOR THE SIXTEEN TEXTS FROM THE EIGHT ELIGIBLE ENGOS

TABLE 5: THE ODDS OF THE DEVIANT AND NON-DEVIANT ENGOS MAKING NONNEGATIVE REFERENCES TO NUCLEAR POWER IN PRE- AND POST-RENAISSANCE PERIODS 


\section{CANADIAN ENVIRONMENTAL NON-GOVERNMENTAL ORGANIZATIONS' POSITIONS REGARDING NUCLEAR POWER IN ONTARIO}

Master of Applied Science, 2009

By Jay P.D.Wilson

Environmental Applied Science and Management

Ryerson University

\section{ABSTRACT:}

The purpose of this study was to determine if Canadian ENGOs are less opposed to the use of nuclear power in Ontario since 2001 and to determine if any changes are due in part to a broader response to concerns over climate change. Analysis included interviews of fifteen ENGO employees from fourteen Ontario-based Canadian ENGOs and text analysis of nine ENGOs.

There is some evidence that some of the ENGOs studied have in fact softened their stance on nuclear power to become slightly less negatively disposed to the technology, but not more positively disposed. This analysis revealed evidence that two of the fourteen ENGOs may have become slightly more neutral in their references to nuclear power. However, only one of the two organizations shifted its stance due to the concerns over climate change and desire for $\mathrm{CO}_{2}$ emissions reductions. 


\section{1-0: INTRODUCTION}

Certain gases in the earth's atmosphere absorb and re-emit the long wave radiation emitted from the earth's surface; this allows for retention of heat energy that would otherwise be lost to space. This layer of gases is largely responsible for the planet's relatively small temperature changes between day and night (small compared to other planets with little or no atmosphere). The "Green House Gases" (GHGs) that make up this layer include the naturally occurring Carbon Dioxide $\left(\mathrm{CO}_{2}\right)$, water vapour and Methane $\left(\mathrm{CH}_{4}\right)$ gases, as well as certain artificial gases, such as Chloroflourocarbons (CFCs). The warming effect of these gases is sometimes called the "green house effect", and is an important function of the atmosphere. However, recent increases in the concentrations of certain anthropogenic (i.e. human-generated) greenhouse gases have led to concerns over possible increases in global average temperatures (UNFCCC, 2009). This human-caused "global warming" is often referred to as Anthropogenic Climate Change (ACC).

ACC has been a concern to environmental activists for some time (Gore, 2006). In recent years, ACC has been an issue of concern for governments and the general public as well (G8, 2009). The reduction of $\mathrm{CO}_{2}$ and other $\mathrm{GHG}$ emissions is thought to be able to mitigate the effects of climate change and various technologies have been promoted as a means to do so. Low-GHG-emitting electricity generating technologies include solar photovoltaic (PV) power, wind power, hydroelectric power and nuclear power. While each method of generating electricity comes with its own environmental challenges, nuclear power has long been opposed by activist groups (Mehta, 2005).

Combustion-driven methods of generating electricity (such as burning coal) burn the fuel in air producing water, carbon dioxide and heat as well as other gaseous and particulate by- 
products. The heat produced in the combustion reaction is absorbed by water which expands as it is heated, eventually becoming steam. As the heated water is in a closed vessel, the pressure increases to many times the atmospheric pressure. This pressure is relieved by venting steam through a turbine that drives an electrical generator. As the steam is decompressed, the temperature drops and the water begins to condense into liquid form. The decompressed water is then cooled further and subsequently reheated as the cycle begins again.

Nuclear power, like coal power, involves heating water in a closed system until it becomes a pressurized gas. Unlike combustion-driven plants, a nuclear power plant uses fission, whereby the nuclei of heavy atoms (typically isotopes of uranium) are split through collisions with neutrons, which in turn produce smaller nuclei of various elements, more neutrons and heat (WNA, 2009a).

One of the chief advantages of fission over combustion is that fission produces almost no airborne emissions. Compare this with coal-powered combustion which produces sulphur and nitrogen oxides that contribute to smog, respiratory distress and acid deposition among other problems (OCAA, 2009b; Markandya and Wilkinson, 2007). However, there are numerous disadvantages associated with fission. These include the production of toxic and radioactive solid and liquid wastes, airborne emissions of particulate matter, GHGs and other airborne pollutants during the mining and production of uranium fuel. There is also a risk of catastrophic accidents and generally high costs of nuclear power compared to other energy sources (OCAA, 2005; Markandya and Wilkinson, 2007).

Over the past thirty years, there has been an increase in attention paid to the policy contributions of non-governmental organizations (NGOs) (Betsill \& Corell, 2001). Internationally, treaties and agreements such as the Treaty to Ban Landmines (ICBL, 2009) and 
the Kyoto Protocol (UNFCCC, 2009) were influenced by NGO groups. In Canada, the Ontario Green Energy Act (2009) was written with significant input from ENGOs (GEAA, 2009).

Historically, ENGOs have opposed nuclear power; concerns have ranged from safety, proliferation of atomic weapons and environmental and health risks from mining and waste disposal. However, in recent years certain individuals such as Patrick Moore (consultant and former Greenpeace activist), Stewart Brand (of the Whole Earth Catalogue) and James Lovelock (creator of the Gaia theory) ${ }^{1}$ have voiced their support for nuclear power based on its perceived ability to reduce GHG emissions (Brand, 2007; Lovelock, 2004; Moore, 2006). However, there does not appear to be a similar change in the stances of ENGOs. The nuclear industry has been in decline in North America since popular support for the technology eroded after the 1970s and early 1980s (and often attributed to the combination of the Three Mile Island and Chernobyl accidents in 1979 and 1986, respectively); but interest in addressing ACC with low-emission power has caused a resurgence of interest sometimes referred to as the 'nuclear renaissance,2 (WNA, 2009).

The Ontario government has recently committed to building nuclear power plants to meet electricity demand before maximizing conservation and renewable generation (Ontario Power Authority, 2009). If we assume that the Ontario government values ENGO opinions on energy policy, there are two possible situations: one, that ENGOs have reduced the intensity of their opposition to nuclear power for some reason, and agree with the government's assessment of the

\footnotetext{
${ }^{1}$ Moore, Brand and Lovelock are or have been heavily involved in the environmental movement over the years; they are all relatively well known in activism circles and so their support of nuclear power has stimulated debate over the environmental benefits of nuclear power.

${ }^{2}$ In the January 28 State of the Union Address, President Barack Obama affirmed the United States government's commitment to increasing employment by investing in energy and infrastructure. In the President's words, in order "to create more of these clean energy jobs, we need more production, more efficiency, more incentives. And that means building a new generation of safe, clean nuclear power plants in this country" (Associated Press, 2010). Thus, it seems that, at the time of the writing of this thesis, the US government is still considering nuclear power to be "clean energy".
} 
need for nuclear power above what alternative sources will be able to provide; or two, that ENGOs have not significantly changed their stance on nuclear power, and the Ontario government has disregarded the ENGO position and made the decision to pursue nuclear power anyway.

It would be interesting to determine which of the two preceding situations is more correct in reality. However, this study focuses on the second possibility, that ENGOs may have shifted their thinking in regard to nuclear power because of a more immediate or dire threat: ACC.

\section{1-1: PURPOSE}

This thesis intends to address the following questions: Are Canadian ENGOs less - opposed to the use of nuclear power in Ontario after 2001 compared to before $2001^{3}$ ? To what extent is any change in opposition due to nuclear fission's negligible GHG emissions? To answer these questions, fifteen employees from fourteen ENGOs were interviewed in order to determine their opinions on and levels of support for nuclear power in Ontario. The documents of two of the fourteen ENGOs were subsequently analyzed to compare the ENGOs' positions on nuclear power pre-2001 and post-2001.

The following section consists of background information explaining issues pertinent to this thesis, such as climate change, the nuclear renaissance, NGO involvement in policy formation, and power relationships in democracies.

3 This study focuses on two "eras", pre-2001 and post-2001. Pre-2001, the World Nuclear Association (WNA) considers the nuclear industry to be in decline in North America. Post-2001 is referred to by the WNA as the dawn of the "nuclear renaissance", where interest in nuclear power increases and greater political will exists to pursue nuclear development in North America. More explanation can be found in section 4-5 ("The Study Period"). 


\section{2-0: BACKGROUND}

\section{2-1: Climate Change}

'Climate Change', as the term is used today, refers to the changes that are going on in the earth's atmosphere and the effects of those changes on the climate. While the climate is in a state of constant change and shifting equilibria, there are two key differences between natural variability in weather patterns and the current climate regime. First, there appears to be no historical precedent for such rapid changes in the earth's climate (Gore, 2006); and second, "human impacts appear to be responsible for the major climate changes of recent decades" (UNFCCC, 2009).

A rapidly warming climate may have consequences for both the environment (defined broadly in this context) and human societies. For example, a 3 degree Celsius temperature increase by 2100 - a reasonable estimate according to the Intergovernmental Panel on Climate Change (IPCC) - would cause the extinctions of between $9 \%-31 \%$ of species, more frequent droughts, increased wildfire risk, flood and storm damage and an increase in human mortality as a result of heat waves, floods and droughts (Mann \& Kump, 2008; UNFCCC, 2009).

\section{2-2: CLIMATE CHANGE IN THE PUBLIC EYE}

As the potential problems associated with $\mathrm{ACC}$ have been made increasingly apparent, political support for action to combat it has been growing around the globe. Many governments have acknowledged the importance of the issue; 184 parties have ratified the Kyoto Protocol (UNFCCC, 2009). The support for climate change action is so great that when the federal 
governments of the United States and Australia refused to ratify the agreement ${ }^{4}$, cities and states in the two countries "ratified" the protocol themselves, committing to the required Greenhouse Gas (GHG) reductions despite the lack of federal support (GBCA, 2006; Seattle.gov, 2007). More recently, the 2009 G8 summit in L'Aquila, Italy listed "climate changes" as the fourth item on Italian president Berlusconi's agenda (G8, 2009), after economic concerns.

In the past few years, $\mathrm{ACC}$ has become something of a cause célèbre, enjoying attention in the popular media. Former US vice president Al Gore's documentary film about the participant, An Inconvenient Truth won an Academy Award (Academy of Motion Picture Arts and Sciences, 2006). As well, the accompanying book of the same name was a New York Times bestseller in 2006 (Business Wire, 2007). Gore subsequently shared the 2007 Nobel Peace Prize with the IPCC for their work on the climate change issue (The Nobel Foundation, 2007).

As much as ACC is a major concern in international politics in general, it is the dominant issue on the environmental activism agenda in Canada. On the home pages of four prominent international, national and provincial Environmental Non-Governmental Organizations (ENGOs): Greenpeace, David Suzuki Foundation, The Pembina Institute and the Ontario Clean Air Alliance (OCAA), ACC is referenced directly and indirectly several times on each, and those references appear in prominent locations on each of the homepages (The Pembina Institute, 2009; Greenpeace Canada, 2009; David Suzuki Foundation, 2009a; OCAA, 2009a)

There are two broad responses to ACC: adaptation (the alteration of human activities to "fit around" the new circumstances of the changed climate) and mitigation (the changing of human activities in order to reduce the causes and presumably reduce the impact of further climate change). As mentioned above, certain effects of climate change are already occurring,

4 Australia initially refused to sign the Protocol, but later ratified the agreement on December 3, 2007 (The Sydney Morning Herald, 2007). 
and as such some adaptations are already taking place. For instance, the reduced snow cover in mountain areas is being addressed by an increase in the use of snow making machinery for recreational skiing (IPCC, 2007). In addition to adaptation efforts, mitigation, especially the reduction of $\mathrm{CO}_{2}$ and other $\mathrm{GHG}$ emissions is thought to be able to reduce the effects of climate change and various technologies have been promoted as a means to do so (IPCC, 2007). LowGHG-emitting electricity generating technologies include solar photovoltaic (PV) power, wind power, hydroelectric power and nuclear power. While each method of generating electricity comes with its own environmental challenges, nuclear power has long been opposed by activist groups (Greenpeace, 2009b; David Suzuki Foundation, n.d.).

\section{2-3: THE CANADIAN GOVERNMENT'S CLIMATE CHANGE PLAN}

The Canadian federal government has, on its Environment Canada website, claimed that it supports an "aggressive approach to achieve real environmental and economic benefits for all Canadians" (Environment Canada, 2009). To this effect, the Canadian government is committed to "reduce Canada's total greenhouse gas emissions by 20 per cent from 2006 levels by 2020 and 60-70 per cent by 2050" (Office of the Prime Minister, 2009). The plan for achieving these reductions includes several strategies. Reducing GHG emissions from the electricity sector is specifically targeted, with a goal of $90 \%$ of electricity coming from "non-emitting sources such as hydro, nuclear, clean coal or wind power" by 2020 (Environment Canada, 2009). As well, tighter regulations on the car and light truck sector of transportation, increased US-Canada cooperation on clean energy matters through the continued advancement of the Clean Energy Dialogue, $\$ 2$ billion worth of investments (focusing on renewable technology) through the Economic Action Plan and "playing an active and constructive role at the UN Climate Change 
Conference in Copenhagen". The Environment Canada website also mentions that due to the economic downturn in 2009, the government of Canada is "taking the opportunity to fine-tune our approach to tackling climate change" (Environment Canada, 2009); although it is unclear exactly what "fine-tune" means in this context, the wording on the website implies that climate change has been demoted on the government's agenda.

\section{2-4: THE ONTARIO GOVERNMENT'S CLIMATE CHANGE ACTION PLAN}

The government of Ontario has, on the Ministry of the Environment's (MOE) website, voiced its support for climate change action, citing that there are "opportunities for Ontario to prosper and grow in the new green economy" (Ministry of the Environment, 2009). As with the federal government's plan, Ontario plans to reduce GHGs through investing in lower-emission electricity, transportation upgrades and rebates and incentives for consumers to conserve and upgrade to higher efficiency products. The Ontario plan differs from the federal plan in its focithe MOE specifically targets "renewable energy" rather than "non-emitting" energy and rapid transit investments rather than emissions regulations for cars. The recently passed Green Energy Act also includes serious provision for renewable energy investments for both industry and consumers, and the government's Interim Power Supply Plan (IPSP) goes into further details on how the Ontario government will achieve suitable emissions targets while supplying electricity for a growing population and economy. Other tactics not seen on the federal agenda include a "Next Generation of Jobs Fund" ( $\$ 1.15$ billion for attracting high-paying jobs by encouraging the sale and use of "green" technologies in Ontario) and the use of the Greenbelt Act to control growth and urban sprawl, encouraging a "more sustainable, energy-efficient [and] transitfriendly communities" (MOE, 2009). 


\section{2-5: ONTARIO'S INTEGRATED POWER SYSTEM PLAN (IPSP)}

In Ontario, the provincial government has recently released its plans for the energy future of the Province. The Integrated Power System Plan (IPSP) "is designed to assist, through the effective management of electricity supply, transmission, capacity and demand, the achievement of the government of Ontario's goals identified in the Supply Mix Directive (i.e. the "Directive")" (Ontario Power Authority, 2009, p. 1). Nuclear power will play a major role in providing electricity for the Province for decades to come through new builds and refurbishments of existing reactors. According to the Directive the Province's priorities are, in order of importance:

1) maximize feasible cost effective contribution from energy efficiency, demand management, fuel switching, and customer based generation;

2) maximize feasible cost effective contribution from renewable sources;

3) make up baseload requirements remaining after Steps 1 and 2 above with nuclear power;

4) replace coal-fired generation with power from committed and planned resources [including natural gas-fired generation]. (OPA, 2008:2)

The "Directive Priority" puts conservation, customer-based generation and renewable power in the pre-eminent position above nuclear power. However, according to the OPA, the priority order that the resources were placed in do not translate to priority order in terms of implementation and deployment. Specifically, nuclear resources "that are being pursued directly by the government of Ontario" (OPA, 2008:3) are mentioned separately from the Directive Priority; the nuclear resources mentioned there "will be determined in accordance with the government's RFP process... and related initiatives... and not in the IPSP application" (OPA, 2008:4). Therefore, even though renewables, conservation and customer-based generation have "Directive Priority" in the IPSP, it would appear that the lower-ranking priority item ("baseload 
requirements" from nuclear power) will be given pre-eminence by virtue of its operating outside of the IPSP application process.

This being said, the IPSP does address conservation, renewables and other non-traditional power generation methods. First, the Directive's conservation goal is to reduce electricity demand by $1,350 \mathrm{MW}$ by 2010 and by a total of $4,950 \mathrm{MW}$ by 2025 (OPA, 2008:7). These reductions are in addition to a reduction of $1,350 \mathrm{MW}$ that was to be achieved by 2007 , and are to be met by a combination of the following tools: efficiency, demand reduction and conservation behaviour, self-generation and fuel switching. In addition, the OPA was actively interested in exceeding these conservation targets where doing so would be cost effective.

Second, the creation of new renewable energy supply goals are 10,402 MW by 2010 and 15,700 by 2025 (OPA, 2008:10). "Renewable" energy in this case refers to hydroelectric, wind, solar and biomass generation. The OPA planned for hydroelectric to be the most economically feasible of the four types. The Standard Offer Program (whereby excess consumer-generated renewable power is sold back to the grid at a premium price) was thought to encourage biomass and small-scale wind and solar operations for a proportion of the goal; the remainder to be made up by large scale wind "farms". Unlike conservation, investment in renewable energy was not to exceed the goals of the Directive due to the low cost-effectiveness of the "incremental renewable resource", large scale wind farms (OPA, 2008:10).

Third, nuclear resources are to make up for approximately $35 \mathrm{TWh}$ worth of baseload requirements that will be lacking by 2020 . The OPA determined that either nuclear or combined cycle gas turbine (CCGT) generation would be able to fill the gap in baseload power supply, but that nuclear power had been demonstrated to be the superior of the two technologies (OPA, 
2008:19). The nuclear resources were to be built either by building new reactors or by refurbishing the Pickering B plant, the latter option being preferred for cost reasons.

The Province of Ontario has committed itself to the creation or maintenance of 14,000 megawatts (MW) of electricity from nuclear resources between 2006 and 2026 (Ontario Power Authority, 2009). The IPSP included plans to build new reactors, initially more likely at existing sites rather than Greenfield sites, to reach this goal. Three companies have made bids for the first two of these reactors this year: Areva, Westinghouse and Atomic Energy of Canada Limited (AECL).

Westinghouse and Areva had submitted proposals but these bids had not included the all of the costs. AECL had presented the Province with the only compliant proposal; they included their projected overrun costs in the budget with the total coming to approximately $\$ 26$ billion (Hamilton, 2009). This figure far exceeds the $\$ 5-6$ billion estimate tendered by AECL in 2006 and would deplete the entire provincial budget for nuclear maintenance and development for the next 20 years (Benzie, 2009).

As costs of nuclear development in Ontario have risen above the original estimates, need for electricity has shrunk. The global recession, compounded with the manufacturing contraction in Ontario has also reduced the industrial demand for electricity (The Canadian Press, 2009). As well, the summer of 2009 has been uncharacteristically cool - reducing air conditioning needs and therefore commercial and residential electricity demand (Spears, 2009; Independent Electricity System Operator, 2009)

Despite these challenges, the Province has made clear that nuclear power is an integral part of its climate change mitigation strategy. The Province is still committed to the current IPSP (Benzie, 2009). Former Ontario Minister of Energy and Infrastructure George Smitherman and 
Ontario Premier Dalton McGuinty postponed, rather than cancelled, orders for new nuclear capacity, citing cost concerns and reduced electricity demand (Hamilton, 2009).

\section{2-6: FEDERAL AND PROVINCIAL RESPONSIBILITIES REGARDING NUCLEAR POWER}

Federal and provincial responsibilities for nuclear power generation and management are divided in that federal agencies are responsible for regulating nuclear liability, waste disposal, safety, transportation of nuclear and radioactive materials and approvals for environmental impacts of nuclear undertakings. The federal government is the regulator of Atomic Energy of Canada Limited (AECL) which is the Crown Corporation that produces CANDU nuclear reactors. Conversely, the province's responsibilities are in the areas of energy supply policy, mining, power transmission and water quality protection.

Federally, The Canadian Nuclear Safety Commission's (CNSC, the main regulator of the Canadian nuclear industry) mandate covers four areas: "The regulation of the development, production and use of nuclear energy in Canada; the regulation of the production, possession and use of nuclear substances, prescribed equipment and prescribed information; implementation of measures respecting international control of the use of nuclear energy and substances, including measures respecting the non-proliferation of nuclear weapons; and the dissemination of scientific, technical and regulatory information concerning the activities of the CNSC and the effects on health and safety and the environment arising from the development and use of nuclear energy and nuclear substances." (Nuclear Energy Agency, 2006)

The provinces are responsible for the actual operation of the plants, the provision of electricity and the transmission of power. The provinces are the proponents of individual nuclear power projects in that they are the party that purchases the reactors from AECL. The province 
also regulates the emissions from nuclear plants to air and water by setting standards for radioactive materials effluents and air emissions. For example, the Ontario Drinking Water Advisory Committee is currently reviewing the standard for acceptable discharges of tritium to surface waters from nuclear plants. Finally, the province is also responsible for regulating the mining of uranium and the management of mine wastes.

\section{2-7: THE NUCLEAR RENAISSANCE}

Since the late 1970 s and early 1980 s, the North American nuclear industry has been in slow decline (WNA, 2009). Elsewhere in the world, nuclear power plants have been in constant development, especially in Asia and Eastern Europe. The term "nuclear renaissance" refers to the increased interest in nuclear power in North America since approximately 2001 (WNA, 2009).

Interest in nuclear energy has increased for several reasons, according to the World Nuclear Association (WNA):"[i]ncreasing energy demand, climate change, economics, insurance against future price exposure and security of supply" (WNA, 2009).

Why nuclear power has come back to the fore has partly to do with the perceived potential reductions in GHG emissions compared to coal or natural gas generation (Lovelock, 2004; Moore, 2006; Chacon, 2009). Fission, the splitting of uranium atoms that provides the heat used to generate electricity in a reactor, produces no GHG emissions in and of itself.

Combustion, which provides the heat in a fossil fuel powered plant, produces $\mathrm{CO}_{2}$ in large quantities. There is no way to avoid this $\mathrm{CO}_{2}$ production - by definition, combustion is the conversion of organic molecules into water, carbon dioxide and heat. So as fossil fuels fall out of favour and concern for ACC mounts, nuclear power has been reframed as a "green" method of electricity generation. Further, carbon capture projects have only begun scale tests of facilities 
with unpredictable costs and capture quantities. $\mathrm{CO}_{2}$ production has continued to increase in Canada since the Kyoto agreement was accepted, and expectations for carbon emission reductions through current government schemes and new technologies such as carbon capture are not likely to meet carbon reductions targets (The Edmonton Journal, 2009; Solomon, 2009).

Reframing nuclear power as an environmentally responsible choice has been attempted before. Since the late 1970s, nuclear power had been championed for its minimal contribution to acid deposition (i.e. "acid rain") and lower incidence of air pollution (Campbell, 1989).

\section{2-8: TYPES OF POWER GENERATION IN ONTARIO}

The Ontario Ministry of Energy and Infrastructure's (OMEI) webpage notes that Ontario receives its electricity from five broadly defined sources, in the following proportions: over $50 \%$ from nuclear power plants, $22 \%$ from hydroelectric generation, $16 \%$ from coal plants, $6 \%$ from natural gas and the remainder from "alternative energy sources" (OMEI, 2009). Installed capacity in Ontario in 2005, according to Woodstock Hydro (2005), is in the following proportions: $37 \%$ nuclear, $26 \%$ renewable (including hydroelectric), $16 \%$ natural gas and $21 \%$ coal. Nuclear is sometimes referred to as "baseload" electricity because output from nuclear plants cannot be adjusted to match demand. Therefore other technologies, especially natural gas and coal need to be employed along with nuclear power in order to produce enough electricity for peak usage times.

One of the chief advantages of fission compared to coal is that fission produces almost no airborne emissions. Compare this with coal-powered combustion; impurities in the coal fuel produce sulphur and nitrogen oxides that contribute to smog, respiratory distress and acid deposition, among other problems (OCAA, 2005a). The disadvantages of fission include the 
production of toxic and radioactive solid and liquid wastes, airborne emissions of particulate matter, GHGs and other airborne pollutants during the mining and production of uranium fuel, risk of catastrophic accidents and generally high costs of nuclear power compared to other energy sources (David Suzuki Foundation, 2006a; Markandya and Wilkinson, 2007).

\section{2-9: NON-GOVERNMENTAL ORGANIZATIONS (NGOS) IN CANADA}

Over the past thirty years, there has been an increase in attention paid to the policy contributions of non-governmental organizations (NGOs) (Betsill \& Corell, 2001).

Internationally, treaties and agreements such as the Treaty to Ban Landmines (ICBL, 2009) and the Kyoto Protocol (UNFCCC, 2009) were influenced by NGO groups. In Canada, the Ontario Green Energy Act (2009) was written with significant input from environmental NGOs (ENGOs) (GEAA, 2009). As well, the anti-nuclear lobby in Canada comprises of many ENGOs that have been involved in actions against the several nuclear power plants inside and outside Ontario (Mehta, 2005).

There are various mechanisms by which NGOs and ENGOs contribute to the policy formation process, including direct lobbying of policy makers, increasing public awareness of environmental issues and funding environmental action, and acting as a clearinghouse for information and knowledge about environmental issues (Kingdon, 1984).

Historically, ENGOs have opposed nuclear power; concerns have ranged from safety, proliferation of atomic weapons and environmental and health risks from mining and waste disposal. 


\section{2-10: HISTORICAL ROLE OF ENGOS IN AFFECTING NUCLEAR POLICY}

ENGOs have played important roles in nuclear policy across the world at different times. Occasionally influencing or leading public policy, ENGOs are also often ignored in the policy arena by governments and industry. The following is a brief summary of the roles that ENGOs in the United States, Sweden and Canada have played.

The United States has a long and storied relationship with nuclear power and public protest, beginning in 1957 with the opposition to the Fermi I reactor near Detroit, Michigan. The first arguably successful opposition to a nuclear plant was the campaign against the building of a plant on sensitive dunes at Bodega Head, California. The Sierra Club was able to reach a compromise with the project's proponent, Pacific Gas and Electric (PG\&E) which changed the site from Bodega Head to Diablo Canyon, California.

However, this compromise was not accepted by all of the Sierra Club's membership, and the group split over the issue (Gyorgy \& Friends, 1979). Detractors of the Diablo Canyon plan felt that the location was unsuitable for several reasons. The proposed site was considered "unspoiled", there was Native American cemetery at the site and, after construction began, a significant seismic fault line (the Hosgri fault) was discovered not far from the site (Gyorgy \& Friends, 1979). The facility was eventually built amid highly publicized protests, including several blockades of the site. According to the NGO association most often associated with the protest movement at Diablo Canyon, the plant is one of the "most controversial nuclear facilit[ies] in the world due to intense public opposition" (Abalone Alliance, n.d.).

In the aftermath of the Second World War, the Swedish government expressed interest in gaining nuclear weaponry, but over the next two decades the desire for nuclear weapons faded. However, nuclear energy remained a priority over this time, a 1955 government report 
recommended installing between 6,000 and 12,000 MW of nuclear energy by 1975 (Mehta, 2005). However, by 1982, only 3200 MW of nuclear power had been built (Swedish Atomic Forum, 1982).

In 1973, the year of the OPEC oil embargo, the major opposition party in Sweden (the Center Party) assumed an anti-nuclear stance and was partly responsible for a two-year moratorium on nuclear development. The anti-nuclear movement grew under the support from the Center Party and by the mid- to later-1970s tens of thousands of protesters were picketing Swedish nuclear plants, although nuclear power still had support from the ruling Social Democratic Party (SDP). However, in 1979, the accident at the Three Mile Island (TMI) nuclear facility in Pennsylvania caused a dramatic shift in opinion towards nuclear power in Sweden and the SDP reversed its position. The following year a referendum on nuclear power resulted in a commitment to phase out nuclear power by 2010 (Mehta, 2005).

In Canada, as in other western nations, the so-called peace movement (encompassing anti-war and nuclear disarmament groups) was closely tied to the anti-nuclear movement (Wittner, 2009). This link between the military and commercial uses of nuclear technology was made clear to Canadians in 1974 when India, using materials generated in a Canadian-supplied CANDU reactor, built and tested an atomic bomb.

The Canadian anti-nuclear movement at first relied on its American counterparts for information and guidance on lobbying, but the differences between the Canadian CANDU reactor design and the American reactor designs made it easy to dismiss concerns about nuclear energy based on studies of American reactors. As a result, Canadian scientists sceptical of nuclear technology focussed a great deal of energy on informing themselves about the potential risks of CANDU reactors. This led to technical criticisms of different aspects of the nuclear 
industry, including the waste disposal plans outlined in federal government's 1977 report The Management of Canada's Nuclear Waste (also known as the Hare Report) (Mehta, 2005). In part due to the fervent and public criticism by Canadian groups, public support for nuclear power in Canada dropped precipitously from $41 \%$ to $23 \%$ between 1976 and 1983 (Mehta, 2005). The drop in public support did not necessarily translate into a change in government policy; however there have been no new reactors built in Canada since the Darlington nuclear station was completed in 1991.

Policy formation on nuclear power is an area that is more or less cut off from NGO participation. NGOs have access to three hearings that deal with nuclear power: the environmental assessment hearings for nuclear reactor construction, hearings for the creation of the Ontario government's IPSP and waste disposal hearings through the Nuclear Waste Management Organization (NWMO) (NWMO, n.d., OPA, 2008).

Participation in the IPSP hearings does not necessarily translate to influence in nuclear policy, due to the different proposal requirements outlined in Section 2-5. In effect that leaves only two fora where NGOs may have real influence: NWMO and environmental assessment hearings. But these hearings only take place for new waste disposal proposals or new reactor construction projects.

In the late 1980s, Ontario Hydro revealed its plans new nuclear reactors and supplied projections for the expected growth in electricity demand that would necessitate their construction. During the public hearings associated the environmental assessment of the plan, several ENGOs criticized the projections as overly optimistic and unrealistic (Green Energy Coalition, 2008). Eventually, Ontario Hydro's plan was defeated in the assessment. Since then, the IPSP has been the notable opportunity for a hearing on planned nuclear development. 
However, in 2006, the then-Minister of the Environment of Ontario exempted the IPSP from the Ontario Environmental Assessment Act (O. Reg. 276/06), preventing it from receiving public scrutiny. Therefore, NGOs have been cut off from participation in the IPSP policy formation process. Therefore, by the time that the IPSP is implemented and new nuclear power facilities reach the environmental assessment stage, many of the important decisions will have already been made without formal input from the NGO community.

So, while ENGOs are able to exert a great deal of influence in some policy areas, nuclear power policy in Canada remains relatively off-limits except under rare circumstances such as environmental assessments for individual nuclear power projects. This explains the apparent lull in ENGO action regarding nuclear power in Ontario over the past 20 years. It is not evidence of ENGOs' apathy toward nuclear development; rather, it demonstrates that there have been no fora in which ENGOs might influence nuclear power policy.

Overall, it is difficult to say exactly how much influence anti-nuclear NGOs have had on government nuclear policy. There is evidence that supports the assertion that NGOs have some influence over political matters (Betsill and Corell, 2001); exactly how much NGOs were able to influence their respective governments is anyone's guess. For example in the Canadian case, the timing of the protests against the Darlington nuclear plant happened to overlap with the Chernobyl disaster and stagnant electricity demand. As well, construction delays and cost overruns associated with the project were well publicized and unpopular. All five of these factors (Protest, lower demand, cost overruns, delays and the Chernobyl disaster) likely played important roles in eventually halting new nuclear development in Canada - but defining exactly how much each factor affected policies is difficult to define. 


\section{2-11: CHANGES IN ENGO POLICY INFLUENCE}

The NGO community has grown dramatically since the turn of the twentieth century, and these organizations have had a significant influence on environmental politics (Corell \& Betsill, 2001). Betsill and Corell point out that "virtually every study of international environmental issues mention[s] NGOs as important actors" (Betsill \& Corell, 2001, p. 65). Wapner echoes this statement, writing that "over the past decade or so...there has been a virtual explosion of interest in NGOs [and their influence on world political affairs]" (Wapner, 2002, p. 37).

Unlike examples of international participation in policy formation, examples of participation at the national level are somewhat less well-known. The pro-liberalization championed by the Adam Smith Institute (ASI) and Institute of Economic Affairs (IEA) in Britain in the 1970s and 1980s is one example of a national policy being influenced by a nationally-focused NGO (Stone, 2000). In Canada, the Canadian Clean Air Act (2006) and the Ontario Green Energy Act (2009) were both written with input from ENGOs (GEAA, 2009). The Lake Simcoe Protection Act (2009) was championed and eventually attributed to a coalition of NGOs collectively referred to as Campaign Lake Simcoe (Environmental Defense, 2007). As well, the ENGO Save The Oak Ridges Moraine (STORM) successfully lobbied for an Oak Ridges Moraine Conservation Act (STORM, 2002).

Other than nuclear policy, NGOs have been active and influential in policy formation around the world, including economic policy (privatization and liberalization in the 1970s and 1980s),' human rights (boycotts of South Africa during apartheid) and the environment (the Forest Stewardship Council).

For example, in Ontario alone, there are 1021 environmental NGOs listed on the Ontario Environmental Directory (Ontario Environmental Network, n.d.). The Canadian NGO sector as 
a whole consists of approximately 55000 separate organizations, comprising $7.3 \%$ of Canada's GDP (Anderson, 2007; Thompson, 1996). According to Statistics Canada, the 2005 income for the non-profit sector, excluding hospitals, universities and colleges totalled $\$ 68.75$ billion, giving a slightly more conservative figure of approximately $5.0 \%$ of GDP (Statistics Canada, 2005).

Tactics used by NGOs include raising public awareness, lobbying state policymakers, coordinating boycotts, participating directly in international negotiations and acting as a watchdog in order to ensure compliance with international agreements (Betsill \& Corell, 2001)

Stone, in her analysis of the strategies used by independent policy institutes ("think tanks"), notes that "policy transfer does not necessarily require governmental involvement but can occur between corporations, international organizations and NGOs" (Stone, 2000). While her analysis focuses strongly on think tanks, she reasons that because most are non-profit organizations and are intellectually independent from vested societal interests, they are analogous to NGOs.

NGOs also potentially influence decision makers and stakeholders by providing information to negotiators (Betsill \& Corell, 2001; Lovelock, 2002). Presumably, informing the general public would also help to influence policy makers by encouraging non-ENGO citizens to pressure their officials as well (Forester \& Stitzel, 1989). In other words, while "states have military and political resources and the private sector has economic resources...the provision of knowledge and information is the key NGO resource for influence" (Betsill \& Corell, 2001, p. 72).

Stone echoes these observations, adding that there are four primary ways that NGOs diffuse ideas, by (1) providing information; (2) being advocates for policy changes; (3) by developing and nurturing networks of business people, politicians, bureaucrats and activists; and 
(4) by providing expertise and intellectual products on their chosen policy issues (Stone, 2000, p. 46).

Wapner's evaluation of NGO influence centres on the NGOs role as a "cultural agents that shape the way vast numbers of people understand themselves and the world around them" (Wapner, 2002, p. 48). He adds: "notions of right and wrong, good and bad, hip or unhip, and other valuations change under various socio-historical contexts. NGOs try to identify and manipulate the ideational codes underpinning such valuations..., they work to shape personal identity and the broader "moral intellectual universe" within which societies operate" (Wapner, 2002, p. 38).

There are several studies in the literature that assert that NGOs influence policy. However, the criteria for what constitutes influence can vary from study to study. Some studies (Bjorkbom, 1999) have assumed that NGO access to negotiations constituted influence; others (Short, 1999) that the presence of NGO-written text in the final policy documents was an acceptable indicator. Betsill and Corell contend that there are different definitions of influence, and therefore comparison between studies is problematic (Betsill \& Corell, 2001). Occasionally, policy makers will give credit to NGOs directly in their communications. For example, as Britain was privatising many of its publicly-owned services in the late seventies and onward, NGOs such as the Adam Smith Institute (ASI) and the Institute of Economic Affairs (IEA) provided much of the intellectual legitimacy for privatization in that country. Later, in 1998, former British Prime Minister John Major remarked that "we could not have a more powerful advocate of privatization and liberalization that the Adam Smith Institute" (Stone, 2000, p. 55).

There are three main reasons why governments still respect and value NGO opinions. The first is that NGOs have the ability to communicate environmental facts that would 
undermine government and public positions on environmental policy. The second is that NGOs have sizable constituencies that they communicate with and can influence to vote certain ways. A prime example is the American Association of Retired People (AARP), an organization that has grown from a sizable 33 million members in 2008 to approximately 40 million members in 2009; the organization is a significant influence in American politics (Allf, 2008; AARP, 2009). Third, NGOs have a high level of credibility with the public; they are trusted sources of information and leadership (World Economic Forum, 2006).

Finally, NGOs influence policy by altering the cultural landscape and therefore changing the way the public as well as policy makers view certain issues. For example, Amnesty International pressures actors directly through lobbying as well as campaigning to get people to change the way they conceptualize their fellow human beings (Wapner, 2002).

As well, Betsill and Corell note that some influence indicators are more appropriate than others; regarding efforts as evidence of influence is likely to show greater influence levels than actually exist. According to the authors, correlating a particular ENGO position with an outcome addressing that position is a better method of determining influence. In their words, NGO influence has "two dimensions: 1) the intentional transmission of information by NGOs and 2) alterations in behaviour in response to that information" (Betsill \& Corell, 2001, p. 72).

There is a wealth of information regarding NGO participation in international negotiations. The Mine Ban Treaty, signed in 1997 by 122 states, owed much of its success to the involvement of international NGOs (ICBL, 2009). Similarly in Canada, the effect of the ENGO Environmental Defence Canada on regulating BPA in baby products is widely acknowledged (Foster, 2009). 
Beyond ENGO numbers and constituencies, there is strong anecdotal evidence that NGOs are able to exert a significant influence over industry. For example, Greenpeace campaigned for the removal of Genetically Modified Organisms (GMOs) from Gerber baby food products in 1999. Gerber's then-parent company Novartis claims that they were "considering the move to non-GMO ingredients even before [Greenpeace] asked for information on the company's use of biotech ingredients" (Edie News, 1999); however, Greenpeace's intention was to demand action on GMO use in baby foods, it acted in order to elicit a response from the policymaker and prompted a change in the policies of the company.

Firstly, Greenpeace is a major organization with tens of thousands of supporters around the world, able to mobilize large numbers of people and considerable resources to influence and steer public opinion on environmental matters; Greenpeace's position on GMOs could be representative of consumer preference for those thousands of members and supporters. Secondly, the relationship between Novartis and Greenpeace would be best described as adversarial, and the corporation would not necessarily be willing to concede defeat by acknowledging they had bowed to ENGO pressure on a fundamental aspect of their business (Novartis AG is a major biotechnology seed manufacturer). By citing consumer preference as the reason, they appear to be acting in a rational economic manner by ensuring they are providing what their customers demand. This case serves to illustrate the difficulty in determining exactly how much influence ENGOs may have.

\section{2-12: NGOS AND NON-STATE MARKET DRIVEN (NSMD) MECHANISMS}

Various mechanisms exist outside state influence that encourage and reward responsible behaviour. Standards organizations are an obvious example, such as the Canadian Safety 
Association (CSA) or the International Standards Organization (ISO) series of certifications. CSA certifications are used to denote acceptable standards of safety for products, for example work boots made to withstand a certain amount of damage while protecting the foot, while ISO certifications are rewarded to entire firms. Depending on the level of the certification, an ISO award can denote ability to manufacture consistent products, responsible accounting practices or their environmental impact.

NGOs have sometimes led the way to the creation of NSMDs. For example, the failure of the 1993 Earth Summit to sign a global forest convention provided the impetus for the WorldWide Fund for Nature (WWF) to create a replacement called the international Forest Stewardship Council (FSC) certification system (Cashore, 2002). Another widely accepted international program championed by NGOs is the Fair Trade coffee program, similar in outlook and structure to the FSC.

The FSC and Fair Trade coffee are examples of Non-State Market Driven (NSMD) instruments. These NSMDs are often certification programs that encourage sustainable practices among members through an economic incentive: those who meet the standards of sustainability are paid a premium for their goods by wholesalers and retailers, who in turn sell the product at a premium to consumers. Various NSMD systems similar to the original FSC now exist, and in some cases have negotiated rights to be sold at major retailers such as Home Depot and IKEA (Forest Stewardship Council, n.d.; Ikea, 2008).

NSMD instruments by definition have little to do with governments. They are often conceived and executed without government aid or approval, and do not require the use of force (in the form of fines or incarceration) to encourage their adherents to engage in good behaviour. Instead, partnerships between businesses, NGOs, local individuals, labour organizations among 
others, and any combinations of those groups conspire to manipulate market forces in order to materially benefit members who choose to adhere to the rules of membership. In addition to the pragmatic reasons for joining (the economic benefit of price premiums for members' products), there are two other broad categories of motivations. These are referred to by Cashore as Moral and Cognitive (Cashore, 2002). The former refers to the idea that joining and adhering to the rules laid out with membership is the 'right thing to do'. The latter refers to the idea that at some point, members and future members will look at the appropriate NSMD for their industry, seek membership and adhere to the rules because it is an understandable and acceptable practice for that industry.

For all that NSMDs have accomplished in promoting responsible environmental behaviour, they are not examples of NGOs influencing policy. The near-total absence of government involvement (except in the role of regulating marketplace activities, contract and common law and other roles related to the maintenance of a functional marketplace) precludes NSMDs from influencing government policy to favour the environment. In fact, NSMDs are sometimes encouraged by government agencies as ways of avoiding regulatory responsibilities (Cashore, 2002).

\section{2-13: NGOS AND AGENDA SETTING}

Deciding which issues are to be seriously addressed by policy makers is the first and perhaps the most important step in making policy. There are several viewpoints as to how to get a specific issue on the agenda of a given legislative body. First, in liberal democracies, constituents may appeal to their representatives in the hopes that they will carry the issue to the legislature to be addressed. A second, more cynical view is that the public is generally 
uninformed, uninterested and unqualified to make policy suggestions; in this view, the role of the public is confined to the electoral process (Hessing et al., 2005). Current restrictions on public involvement in the policy process may benefit the public as they allow experts to form the necessarily complex bureaucratic and scientific policies that the general public would not be able to comprehend and therefore would make serious errors in trying to create policy (Hessing et al., 2005). Thus, government policy creation is left in the hands of the technocracy. As described by Torgerson, in "... advanced society, there is a distinct and widely noted tendency for public policy analysis to become virtually absorbed in narrow, technical issues... [and] calculating solutions for specific problems [with] strictly delimited frameworks (Torgerson, 1985:245).

However, there are forces that are opposed to the type of government staffed by a technocratic elite. Stallen and Koppock (1987) assert that it is essential for the public in a democratic society to be knowledgeable in order to have an effective government. Likewise, Linnerooth (1984) asserts that in an ideal situation regulations should be created within a threeparty framework of government, industry and the public.

There are many examples of neo-liberalization in Britain, the United States and Canada where smaller, less intrusive government policies were pursued for both ideological and pragmatic reasons (Stone, 2000). Environmental and social issues in particular have been influenced by direct public involvement in recent years. But the setting of the agenda seems to be well entrenched in the hands of the policy makers rather than the public. In the words of public policy thinker John W. Kingdon (1984):

The agenda, as I conceive of it, is the list of KIs or problems to which governmental officials, and people outside of government closely associated with those officials, are paying some serious attention at any given time... Out of the set of all conceivable KIs or problems to which officials could be paying attention, they do in fact seriously attend to some rather than others. So the 
agenda-setting process narrows this set of conceivable KIs to the set that actually becomes the focus of attention.

As described by Hessing et al. (2005), the agenda setting capacity of any particular policy area is defined by the level of public interest and the level of enthusiasm for which the state is willing to accommodate public involvement. For example, while resource extraction has historically been held above environmental concerns, the environmental community has made inroads to several steps of the policy making process. The public and NGOs have a greater role in consultation and negotiation, and have greater financial support from governments and greater standing in courts and tribunals (as delineated in the Ontario Environmental Bill of Rights [OEBR]) in order to facilitate their policy-influencing activities (Ontario Environmental Network, n.d.a).

Despite this progress, the setting of the agenda is still largely the domain of the government officials and their closely associated non-governmental colleagues. The evidence for this is that none of the accommodations that governments have provided to the public have resulted in a major shift in the way that the government treats natural resources; the "rhetoric of public participation is primarily geared toward discretionary forms of public consultation rather than mandatory and adequately supported inclusion on formal agenda-setting bodies" (Hessing et al., 2005).

The public has neither the economic nor the institutional means to compete with traditional agenda-setting forces. Indeed, even as more provisions were allowed for token public participation, these allowances did as much to reinforce the legitimacy of state dominance over the agenda as it did to further the democratic rights of a concerned public (Hessing et al., 2005). However, public participation allows for collective action; fundraising campaigns bridge the gap 
between NGOs and governments or proponents, at least economically and elevate the NGOs ability to negotiate.

Evidence of this bias is found in the treatment of the Lands for Life consultation process by the Harris government in Ontario in the 1990s. Ballamingie found that the government was in control of who would consult the public, how the consultation would be done and what questions could and could not be asked in the consultations (Ballamingie, 2009). These controls led to the formation of a panel sympathetic to industry and dismissive of environmental claims, the selection of meeting places that were inappropriately formal (upscale hotels etc.), and the exclusion of First Nations' representatives (treaty rights, land claim resolutions and critiques of land management practices were considered to be outside the periphery of the consultations, even though 30,000 native people lived in the areas under evaluation) (Ballamingie, 2009).

\section{2-14: THE NATURE OF SITING CONFLICTS}

There are two common conflicts related to nuclear power plants; these are shared with other kinds of industrial facilities. The first common conflict is the broader environmental opposition to the existence and operation of the facility itself, regardless of whether the opponents live or work nearby. The second common conflict is the "Not In My Backyard" (NIMBY) response, where local residents oppose the siting of a facility because they perceive that harm will be done to them due to their proximity to the site.

NIMBY is a manifestation of public's distrust for planners and governments to always safeguard the public (Inhaber, 1992b). Often, the term is invoked when describing difficulties in siting environmental hazards such as garbage dumps or power plants; however, NIMBY responses have happened in response to proposed homeless shelters, AIDS hospices and even 
daycare centres (Inhaber, 1992b). Disputes over the sites are always centred around the location for their operations, never on the existence of the site somewhere - citizens are likely to agree that toxic waste must be safely stored somewhere, but very unlikely to propose that they be the ones to accept such a storage facility in their community.

Starting in the mid- $20^{\text {th }}$ century, more attention has been paid to citizen's groups who were in opposition to certain industrial facilities and operations; since then these groups have become more prevalent in society and increased their visibility, membership and influence (Betsill \& Corell, 2001; Wapner, 2002). Previously, an industrial facility might be sited simply to maximize economy based on land values and proximity to inputs and transportation routes. Local populations often had little say in the matter, unless they were willing to organize and fund legal challenges to siting activities. Today, industries and governments now have a more difficult time finding suitable locations for undesirable facilities because they must appease a more organized, empowered citizenry in the process (Inhaber, 1992a).

\section{2-15: THEORETICAL EXERCISE OF POWER}

Some scholars believe that the public is the source of all power in a democracy; and the public chooses to give up that power to the government. The public produces power as a good, and supplies it to officials in the form of legitimacy. This is "the impotence of the powerful they have to borrow their power from the producers of power" (Habermas, 1977). Thus, the public ànd its representatives are equals according to this viewpoint. Forester and Stitzel describe this kind of information sharing as communicative power: the ability to correct misinformation that prevails in the ruling structure and to offer legitimate information in planning assistances to allow collective decisions to reflect the public's interests (Forester \& 
Stitzel, 1989). In the ideal world, people would freely and collectively communicate their preferences and arrive at decisions.

There are stumbling blocks that prevent this kind of communicative power from being realized. One such hindrance is structural influence; which effectively blocks those communications that would serve to form legitimacy. It keeps the two actors, the public and the officials, separate. As Sager asserts, by invisibly separating and hindering the communication between these two groups, social inequality (such as the inequality of power between the public and government officials) can therefore be seen as a "natural" or endemic fact of life (Sager, 1994). Structural influence is an artificial construct in power relations; however, it is not the result of any conscious effort - "nobody is behind [structural influence]; it is impersonal" (Sager, 1994).

\section{2-16: SIGNIFICANCE OF THIS STUDY}

ENGO opinions are important in the Canadian environmental policy making arena. This is due to the fact that Canadian governments have in the recent past taken ENGO opinions into account when creating legislation. This researcher believes that examples described previously show that that governments in Canada value ENGO input and expertise when it comes to environmental matters and are not opposed to listening to and acting on ENGOs' suggestions.

ENGOs, especially those of interest to this study, generally support the theory of ACC and consider it to be a great threat to human health, ecosystems and the economy. These ENGOs support lowering greenhouse gas (GHG) emissions to achieve lower average global temperatures over time. Energy production technologies such as solar photovoltaic (solar PV), hydroelectric, wind, geothermal and various other sources of energy (broadly referred to as "renewables") are 
often considered means to this end. Recently, the Ontario Green Energy Act has entrenched those preferences for renewable energy into law by providing various policy mechanisms designed to promote investment in renewable technologies. One such mechanism is the feed-in tariff, where a premium is paid to the harnessers of a certain renewable energy such as solar PV (Toronto Centre Provincial Liberal Association, 2009).

Besides renewable energy, electricity conservation is heavily promoted in the ENGO literature. Many prominent ENGOs prefer conservation over increased production of electricity, asserting that it is cheaper, cleaner and easier than building new generation facilities (David Suzuki Foundation, n.d.; Pollution Probe, 2009). For example, David Suzuki, namesake of the influential David Suzuki Foundation, has been recently made the spokesperson of the PowerWise program, geared at reducing electricity use through end-user efficiency measures (PowerWISE, 2009).

This study consists of an examination of ENGO opinions in Canada on the topic of nuclear power. Given the evidence, it is clear that NGOs and ENGOs have had and continue to have a strong influence on policy formation both around the world and in Canada. However, current government plans in Ontario hinge on the building of at least two new nuclear power plants in the near future. This study intends to determine if ENGOs in Ontario have changed their historical stance from anti-nuclear to pro-nuclear to reduce $\mathrm{GHG}$ emissions in order to combat climate change.

Following the assumption that governments should and often do listen to ENGOs' policy recommendations, the Ontario government's plan to renew nuclear development should be reflected in ENGO opinions on nuclear power. 
Historically, many prominent ENGOs have been opposed to nuclear power (Greenpeace Canada, 1980; Turnock, 2001; Pollution Probe, 1975). There have been concerns about radioactive contamination, links to the military applications of nuclear technology, waste disposal and cost issues and so on. Many became vehemently opposed to the nuclear industry after the accidents at Three Mile Island in Pennsylvania in 1979 (Greenpeace Canada, 1980) and Chernobyl in the Ukraine in 1986 (Turnock, 2001).

Given that many prominent ENGOs have historically not supported nuclear power and the fact that these organizations are powerful actors in the policy setting arena, there will likely be conflict between supporters of nuclear power and its detractors. Whether nuclear power will be successfully reintroduced into the current electricity supply system cannot be answered by this thesis. Decisions at the provincial and federal level are being made, changed, reversed and avoided even at the time of this writing. What this research should be able to highlight is the likelihood of opposition to nuclear development in Ontario by Canadian ENGOs. 


\section{3-0: OBJECTIVE}

This thesis intends to address the following questions: Are Canadian ENGOs less opposed to the use of nuclear power in Ontario after 2001 compared to before 2001 To what extent is any change in opposition due to nuclear fission's negligible GHG emissions?

To answer these questions, ENGO employees were interviewed in order to determine their opinions on, and levels of support for, nuclear power in Ontario. In addition, an analysis of texts written or published by ENGOs both before and after the beginning of the nuclear renaissance was completed. Support for nuclear power was compared with positions on climate change in order to see if concern over $\mathrm{ACC}$ has led to a softening of the stance on nuclear power. This information is important - ENGOs are a powerful political force and their support or - opposition of the IPSP could influence public support for nuclear energy. 


\section{4-0: METHODS}

This study seeks to address the research questions stated in Section 3-0. First, the researcher sought to verify or disprove a possible shift in ENGOs' positions on nuclear power since 2001 (as per Crabtree and Miller, 1992). Then, if there was a detectable shift in ENGO position over that time, to determine if it was linked to climate change.

An analysis of ENGO positions over the course of twenty years from 1989-2009 (the "study period") was completed. The length of the study period was arrived at by way of an article by the World Nuclear Association (WNA) titled "The Nuclear Renaissance" (WNA, 2009b). In it, the WNA mentions that "since about 2001 there has been much talk about an imminent nuclear revival or renaissance which implies that the nuclear industry has been dormant or in decline for some time...this may generally be the case for the Western world" (WNA, 2009b). Thus, the study period is divided into two sub-periods, pre-renaissance or pre2001 and post-renaissance or post-2001. The year 2001 was considered to be pre-renaissance.

First, the term ENGO was defined. Then, ENGOs were selected to participate in the interview process. Then potential Key Informants (KIs) were selected from those ENGOs and the process of initiating a dialogue with potential KIs began with the recruitment phase. After recruitment, the interviews were performed. The resulting interviews were then transcribed and analyzed. Then, the ENGOs were evaluated for their suitability to have their publications and texts analyzed; one ENGO was selected to be the "deviant case", as described in Silverman (2000). Then, the texts were acquired and analyzed. 


\section{4-1: DEFINITION OF AN ENGO}

NGOs are non-profit organizations that are self-funded by membership fees, merchandising or donations. Such an organization is not affiliated directly with businesses or governments but remains separate and autonomous. It has a constituency, that is, a group of supporters, members, volunteers or citizens that it attempts to act on behalf of. An NGO has a political agenda which guides its actions; this agenda may be broad (i.e. 'human rights', and all that falls under that definition) or more narrow (i.e. the protection of the water quality of a single lake or river). The E in ENGO stands for 'Environmental'; thus ENGOs are NGOs which are primarily focused on environmental concerns, defined broadly. Jasanoff (1997: p580) summarizes a great deal of information in her discussion of what it is to be an environmental NGO:

The term "NGO" can be applied in principle to an enormous range of environmental actors, from tiny, grassroots coalitions of conservationists or pollution victims to mature, well funded, technically expert multinational organisations possessing many of the characteristics of state bureaucracies, but without their political accountability. Some of these groups coalesced from the start around environmental concerns, while others have incorporated environmental objectives into broader agendas of social development. Some NGOS, like Europe's staid nature conservancies, have been in action for more than a century, with practices shaped by culture, place and history; others, like the daringly entrepreneurial Greenpeace, have won a place at the international policy table after less than a quarter-century of world-wide environmental advocacy. Major "nongovernmental interest groups" - political parties, labour unions, industries and trade associations - have spun off a host of specialised NGOS and NGO coalitions to deal with the environmental matters that specifically concern them. Scientific societies and committees, including those established under international regimes, constitute still another class of environmental NGOS with strong claims to political neutrality. Together, these groups display a bewildering diversity of form, function, style and expertise, with missions ranging from research to litigation, from lobbying to community education, and from monitoring to natural resource protection. Clearly, environmental NGOS conform to no simple taxonomy; arguably, the 
only structural feature they have in common is their formal independence from the state.

As Jasanoff (1997) notes above, there are various mechanisms by which NGOs and ENGOs contribute to the policy formation process, including direct lobbying of policy makers, increasing public awareness of environmental issues and funding environmental action, and acting as a clearinghouse for information and knowledge about environmental issues.

Before any KIs were contacted, the researcher applied for and received ethics approval from the Ryerson Ethics Board. Ethics approval was received on February 5, 2009, and interviewing commenced soon after that date.

\section{4-2: SELECTING POTENTIAL PARTICIPANT ENGOS}

This study followed a qualitative method, starting with qualitative sampling strategies. Patton (1990) asserts that qualitative inquiry is typically concerned with small samples that are selected purposefully, in order to achieve information-richness. In contrast, quantitative studies are concerned with large samples that are selected randomly, in order to achieve representativeness. In qualitative research, the researcher must first concern his or herself with finding information-rich data sources and deciding who or what to examine first. Later, the researcher must examine their understanding of the phenomenon they are studying; they must find new data that may confirm, refute and/or enrich their understanding (Lincoln and Guba, 1985). In short, theory in qualitative research will be "modified and confirmed in the context of the study" (Crabtree and Miller, 1992:33). Sampling in this study was based on theoretical sampling as outlined in Glaser and Strauss (1967). According to Glaser and Strauss, "Theoretical sampling is the process of data collection for generating theory whereby the analyst jointly collects, codes, and analyzes his data and decides what data to collect next and where to 
find them, in order to develop his theory as it emerges. The process of data collection is controlled by the emerging theory" (1967:44). In other words, "theoretical sampling is done in conjunction with data collection" (Merriam, 1988)

In order to be selected to participate in the study, ENGOs needed to have an interest in Canadian energy issues; i.e. they must have suggested policy, lobbied governments, employed analysts, organized members of the public and so on and at least some of these efforts must have been focused on issues concerned with energy supply. As well, ENGOs must have had an espoused interest in nuclear power specifically, or energy/electricity supply generally. Second, the ENGO must have devoted resources to communicating with policy makers directly (through lobbying, letter writing, etc) or indirectly (through raising awareness throughout the general public, exhorting members of the public to engage their elected representatives on their issues). Third, ENGOs must have had at least one Canadian office.

The researcher used a directory list of the ENGOs in Ontario (Ontario Environmental Directory) as the starting point for finding potential participant organizations. As well, there were several nationally recognized organizations that were considered important to include based on their size and high public profile. A total of 35 organizations were contacted. Table 1 lists all of the ENGOs which had employees that agreed to participate in the study.

As described in Merriam (1988) and Glaser and Strauss (1967), theoretical sampling was used to find ENGOs according to need as the project progressed. 
Table 1: ENGOs that had potential KIs contacted for interviews who agreed to participate

\begin{tabular}{|c|l|}
\hline$\#$ & \multicolumn{1}{|c|}{ Name of organization } \\
\hline $\mathbf{1}$ & Riverdale Initiative for Solar Energy (RISE) \\
\hline $\mathbf{2}$ & The Environment Committee for a Regional Labour Organization* \\
\hline 3 & Citizens' Environmental Alliance of South Western Ontario \\
\hline 4 & Citizens for Renewable Energy \\
\hline $\mathbf{5}$ & Community Coalition against Mining Uranium (CCAMU) \\
\hline $\mathbf{6}$ & David Suzuki Foundation \\
\hline $\mathbf{7}$ & Grand Erie Energy Quest/Energy Quest for Nanticoke \\
\hline $\mathbf{8}$ & Energy Probe \\
\hline $\mathbf{9}$ & International Institute of Concern for Public Health (IICPH) \\
\hline $\mathbf{1 0}$ & Greenpeace \\
\hline $\mathbf{1 1}$ & Ontario Clean Air Alliance (OCAA) \\
\hline $\mathbf{1 2}$ & Pembina Institute \\
\hline $\mathbf{1 3}$ & Pollution Probe \\
\hline $\mathbf{1 4}$ & Safe and Green Energy (SAGE) \\
\hline
\end{tabular}

*Organization's identity was withheld to maintain confidentiality

\section{4-3: QUESTIONNAIRE - KI RECRUITMENT}

Potential KIs were identified using different sampling theories. Snowball sampling (Patton, 1990) was sometimes used, where a previously interviewed KI would identify other potential KIs for inclusion in the study. Critical case sampling, where "one looks for sources of data that are particularly information-rich or enlightening" was also used by attempting to identify KIs that were particularly involved in the nuclear power or climate change debates (Crabtree and Miller, 1992). As well, a version of criterion sampling was used in that strict selection criteria was applied to all potential KIs to ensure that interviews would provide appropriate and meaningful information (Patton, 1990).

Each potential KI had to be in some way responsible for external communications of the organization for energy or nuclear power specifically and had some policy responsibility. Using 
the ENGO's website, individuals with the words "nuclear", "electricity", "energy" or "climate change" in their title or job description were the first to be contacted. In cases where there were divided responsibilities, i.e., when one organization had both a "Nuclear Power Analyst" and a "Director of Climate Issues" (both of these titles are imaginary, for illustrative purposes only) both of those individuals would be contacted. Where there were more than two individuals with the appropriate words in their titles, all of those individuals were contacted. The reason for this is while in less complex organizations one person could handle the portfolio including nuclear power, climate change and energy, in a larger organization the portfolio was handled by multiple individuals. The focus is the portfolio, and that is why the complete portfolio from each ENGO was sought.

Later in the process, the researcher attended an anti-nuclear rally (No New Nukes in Ontario, March 13-14, 2009) and made note of the employees of several large ENGOs that were presenting there. Several of these individuals were then contacted as potential KIs based on the content in their presentations that made it clear that they worked in the appropriate areas.

During the first round of contact with potential KIs, each participant was first sent an email message denoting the desire for an interview. The script of the email message can be found in Appendix B.

The first six KIs were in fact a small proportion of the total number of potential KIs that were contacted by email. The researcher decided that in order to make the initial contact with potential KIs more likely to result in an interview, potential KIs should be contacted on the telephone instead of by email. It was thought that because of its impersonality, email would allow potential KIs to ignore, defer, or otherwise decline the invitation to participate because there was no human contact. In reaction to this, cold-calling was decided to be more promising 
than cold-emailing. This proved correct when a greater proportion of potential KIs agreed to participate on the first contact by phone than by email. Thus for the remainder of the study all KIs were contacted by phone.

The content of the phone calls was based strongly on the text in the email message. The intent of the initial contact was to ask the person to participate in the project, and committing to an interview time. Most KIs chose to participate in the interview at a future date, but several KIs opted to complete the interview immediately on being asked to participate.

\section{4-4: QUESTIONNAIRE - THE INTERVIEW}

The researcher included at least one of each of the three types of questions defined by Spradley (1979). The three types are descriptive, structural and contrast questions. Descriptive questions could be described as "broadly open-ended" (Crabtree and Miller, 1992). Examples of descriptive questions would be number 4 and number 8 in interview guide 2 . Structural questions are verification questions, used to substantiate some theory of the researcher. Examples of structural questions in interview guide 2 would be questions 14-17, which were used to verify the KI's opinion on nuclear power. Contrast questions include rating questions, for example question 3 in interview guide 2 (Crabtree and Miller, 1992). Please refer to Appendix A for the content of the questionnaire.

A total of fifteen interviews were performed. All interviews were conducted over the telephone, using a recording device and notebook to record the responses. In total, over 450 minutes of interviews were recorded and transcribed, for a total of 48 pages of text. The average interview time was approximately 29 minutes long. Some interviews ran over an hour, while most were in the 18-22 minute range. 
Most respondents were energized during the interview and needed little prompting by the researcher. Where appropriate, probes were used to encourage KIs to elaborate on their answers. For example, "tell me more about that" or "why would that be your response" were used if respondents gave one word answers.

Each interview was recorded on cassette tape, through a device connected to a cellular telephone on which the interview was conducted. After the interview, each interview was transcribed by hand into Microsoft Word and saved as a file named according to the number of the interview. No names of individuals or organizations were included in the transcriptions. Records of which employee was associated with each transcription were kept separate from the transcription to preserve confidentiality.

The interview process was best described as "semi-structured" (Silverman, 2000). This means that the Interview Guide consisted of topic questions intended to evoke discussion. The guide was designed to create a general impression of responses to nuclear power developments in Canada. The open-endedness of the questions encouraged the researcher to constantly reevaluate the topic questions in order to elicit the richest responses from the KIs. As such, in the execution of each interview, there was some variation in the way that questions were asked and the way that probes were used.

Some revisions were made to the questionnaire after the first six interviews. After the completion of the second round of ten interviews with the second version of the questionnaire guide, the first six interviewees were contacted again. Of the six contacted, five agreed to participate further. Each of those five was asked six questions that were not included in the first interview guide, or significantly different between the first and the second interview guide. This 
was done in order to rectify the inconsistency that resulted from using two slightly different interview guides.

\section{4-5: QUESTIONNAIRE - ANALYSIS OF THE TRANSCRIPTIONS}

After the interviews were transcribed, each was analyzed by noting positions in the responses of the participant. In particular, the researcher was looking for words that would be repeated from respondent to respondent, indicating that a common theme was present. The researcher was interested to see whether the KIs were using the same or similar vocabulary to answer the questions. As well, repetitious responses were noted. The responses were similar enough in theme and intent that common opinions could be distilled from the responses to individual questions. In content analysis, this type of reading is sometimes referred to as latent content analysis. In latent content analysis, the meaning of certain sections of text or dialogue is inferred; "the analysis is extended to an interpretive reading of the symbolism underlying the physically presented data" (Berg, 1989:107). Typically, it is best if researchers include in their method a way of corroborating their interpretations of latent meaning. This can be done by including multiple examples that corroborate the interpretation, by including detailed excerpts from the relevant statements, or by comparing the researcher's interpretations other interpreters' or coders' interpretations of the same statements (Heilman, 1976)

Interviews were used for this study in order to elicit the informants' personal values as well as their organizations' values and positions on nuclear power. There was a possibility that the individual's opinions would not match the organization's, but any mismatch would have been inconsequential as each informant would have some degree of organizational fit. If there was a severe mismatch of opinions, the person would likely leave or be pushed out. When hiring, 
organizations would be aware of searching for individuals that viewed issues in the same way. And in smaller organizations that consisted of only a few people, the organizations' position would be inextricably tied to the individuals' positions.

\section{4-6: TEXTS - ENGO SELECTION}

In order to be included in the text analysis the organization had to have been in existence before 2001 and have been publishing documents since at least 2001 which explained their position on climate change and energy policy. Finally, organizations must have named climate change as their environmental issue of primary concern during the interview process. When the criteria were applied to the fourteen ENGOs, there were eight ENGOs that were eligible for textual analysis. Five ENGOs (RISE, CCAMU, the Environment Committee for a Regional Labour Organization, Pembina Institute and SAGE) did not have suitable, available documents or were not in existence prior to 2001. As well, Energy Probe's primary concern was not climate change and was excluded.

However, Energy Probe was included in another part of the analysis. Energy Probe, because of its different stance on climate change, was chosen to be a "deviant case". The purpose of including a deviant case is important to this research because it overcomes "any tendency to select a case which [was] likely to support [the researcher's] argument" (Silverman, 2000:107). The researcher may otherwise select all of the cases simply because they support the argument he or she wishes to make, rather than getting a true picture of phenomenon the researcher is examining.

Since the purpose of this research was to determine if ENGOs were more supportive of nuclear power since 2001 because climate change mitigation has remained or become an important issue, the deviant case consisted of an ENGO which did not agree that climate change 
was a dire environmental concern. The criteria for the selection of the deviant case is the same as for the other ENGOs with the additional requirement that the organization showed evidence of being unconcerned about climate change, or not considering climate change to be the most pressing environmental concern.

Energy Probe was formed in 1969 as an offshoot of the ENGO Pollution Probe; its mandate was to focus specifically on energy issues (Energy Probe, n.d.). It credits itself with being "successful in stopping the construction in Canada of all nuclear plants proposed since [1974]", but unfortunately this assertion does not include an argument that would support it (EP, n.d.). The organization has a somewhat complex relationship with the climate change debate.

The following is from its website:

Because of the enormous amount of research that has since been conducted into climate change - a sum estimated in the tens of billions of dollars - much more is now known about these risks, and much more needs to be known. One of the greatest impediments to this knowledge, however, lies in the mandate of the UN's Intergovernmental Panel on Climate Change (IPCC), which limits itself to man-made causes and thus excludes a needed inquiry into natural causes of climate change. To make matters worse, the many thousands of scientists who question the IPCC's approach are being demonized as "deniers."

To further free scientific inquiry into climate change, Energy Probe has published the dissents of many scientists in [Energy Probe founder and Managing Director] Lawrence Solomon's The Deniers series in the National Post, and in a bestselling book of that name. Energy Probe has also highlighted the social and environmental costs of the Kyoto treaty, which too often receive short shrift. Meanwhile, our sister organization, Probe International, has been working with citizens groups in the Third World who fear for the loss of their livelihoods and their environments as a result of illadvised climate change policies from the IPCC and other western organizations.

It is Energy Probe's position that the climate is in a constant state of flux and there are both natural and anthropogenic causes for that flux. The position of the organization as 
articulated to the researcher by the Energy Probe executive was that while some action to limit the release of GHGs may make sense in some contexts, the costs of the extreme measures that the IPCC proposes will far outstrip any benefits and is certain to cause significant ecological damage in the process. Energy Probe's primary concern, by its Senior Executive's own admission, was not climate change (Energy Probe Senior Executive [Personal Communication], 2009). Thus it was included in order to serve as a deviant case and as a counterpoint to the ENGOs that did view climate change as the most important environmental concern.

\section{4-7: TEXTS - SELECTION OF TEXTS}

A full content analysis of the documentary evidence of NGO positions on the nuclear industry over time is beyond the scope of this study. However, this study was able to compare some of the documentary evidence for nine ENGOs over time.

Permissible texts included position papers or reports intended for policymakers, official summaries of such papers or reports, articles for the website or for publication in periodicals or newspapers, web pages providing general information and books. The search for texts encompassed online searches of ENGO archives, which tended to produce press releases, reports, position papers and summaries for the public and policy makers and libraries for hard copies of texts.

This led to many different kinds of texts being included in the analysis. However, this reflects the disparate kinds of publications and communications that ENGOs produce. To include only one kind of publication would severely limit the available data from different ENGOs. While some ENGOs might produce books but no summaries for policy makers, other ENGOs might produce only summaries, but lack the resources to produce full books. The 
important aspect is that all documents outlined a policy position, the determination of which is the sole purpose of the text analysis.

Books were considered where electronic copies of texts were unavailable. Books were less desirable than electronic copies for practical reasons: hard copies of books needed to be scanned into PDF format for analysis. Several books were long, over one hundred pages in length which made scanning the complete book impractical. In such cases, a summary of the book (for example the introduction, preface, conclusion, abstract, or all of the above), would be considered to be analogous to the text as a whole. The assumption was made that the summaries mentioned above would include the same arguments as the body of the text, or be in the same tone as the body of the text. For example, if the introduction included critical statements about nuclear power, then the rest of the book was assumed to be similarly critical of nuclear power. Using summaries in this way was also acceptable because the length of the text was not important to the analysis.

Two texts from each ENGO were sought, one text from 2001 or before and one from after 2001 and as close to the present day as possible. Each text had to mention the word "nuclear" at least once. Each text was found either in online archives such as those found on ENGOs' websites or in libraries' collections. Any text as described in the previous two paragraphs was considered for analysis if it was authored either by the ENGO as a whole or by an individual writing on behalf of the ENGO.

For the deviant case, four texts were chosen, two from each era. This was primarily done because it was thought that a greater number of texts would impart a greater degree of precision to the analysis. If any conclusions were to be made, it was felt that the conclusions should have 
the support of more than two texts. As well, for the deviant case there happened to be a great number of texts readily available online, while for other ENGOs there was not.

\section{4-8: TEXTS - TEXT ANALYSIS}

For text analysis, electronic copies of publications were downloaded onto a computer while hard copies of the texts were scanned and converted into PDF format. Some of the electronic copies were in PDF format and were analyzed in Adobe Acrobat, others existed in plain text or other formats and were analyzed in Microsoft Word. Having electronic copies was important as it allowed for speedy analysis using the "Find Word" commands in Adobe Reader and Microsoft Word.

Texts were analyzed in order to describe the pre-renaissance era (i.e. pre-2001) compared to the renaissance era (i.e. as recent as possible). This comparison was done in order to find and describe any significant differences between the ENGOs espoused positions on nuclear power from the pre-2001 era to the renaissance era.

The texts were analyzed by locating the words "nuclear", "global warming", "greenhouse gas", "GHG" and "climate change"; each word (other than "nuclear") just mentioned in quotes will be referred to hereafter simply as "Climate Change Indicator Words" (CCIWs).

Paragraphs which mentioned the climate change code words, or the word "nuclear", were scrutinized. For paragraphs with "nuclear" in them, one question was asked: does the author imply that investment in nuclear power is desirable? For paragraphs with any or all of the CCIWs, one question was asked: does the author propose that climate change can or should be addressed using nuclear power? 
These two questions served as tools to illuminate the ENGO's overall stance on nuclear power and climate change. During this process, the total number of mentions of the word "nuclear" per text was tracked in a spreadsheet along with the number of those mentions that were neutral, positively inclined or negatively inclined toward nuclear power. As well, the total number of mentions of the CCIWs per text was tracked in the same spreadsheet, along with the number of those mentions that included a potential role for nuclear power to reduce GHG emissions and those that did not.

Table 2: List of analyzed texts

\begin{tabular}{|c|c|c|c|c|}
\hline & Organization & Text Name & Year & Type \\
\hline 1 & $\begin{array}{l}\text { Citizens' Environmental Alliance of } \\
\text { South Western Ontario (CEASWO) }\end{array}$ & $\begin{array}{l}\text { Citizens Environment Alliance } \\
\text { Congratulates Herb Gray on Climate } \\
\text { Change }\end{array}$ & 2001 & Press Release \\
\hline 2 & Citizens for Renewable Energy (CFRE) & $\begin{array}{l}\text { Newsletter \#6: From the } \\
\text { Coordinator... }\end{array}$ & 1997 & Newsletter \\
\hline 3 & David Suzuki Foundation (DSF) & $\begin{array}{l}\text { Renewable Energy for a Clean } \\
\text { Environment \& Healthy Economy }\end{array}$ & $\begin{array}{c}\text { No } \\
\text { date }\end{array}$ & Report \\
\hline 4 & $\begin{array}{l}\text { International Institute of Concern for } \\
\text { Public Health (IICPH) }\end{array}$ & Victims of the Nuclear Age & 1999 & $\begin{array}{l}\text { Journal } \\
\text { Article }\end{array}$ \\
\hline 5 & Greenpeace Canada (GPC) & $\begin{array}{l}\text { The Greenpeace Book of the Nuclear } \\
\text { Age }\end{array}$ & 1980 & Book \\
\hline 6 & Ontario Clean Air Alliance (OCAA) & Trading Our Health & 1999 & Report \\
\hline 7 & Pollution Probe & The Nuke Book & 1975 & Book \\
\hline 8 & $\begin{array}{l}\text { Citizens' Environmental Alliance of } \\
\text { South Western Ontario (CEASWO) }\end{array}$ & Beyond Nuclear & 2009 & Press Release \\
\hline 9 & Citizens for Renewable Energy (CFRE) & Newsletter \#55: Plant a Solar Tree! & 2009 & Newsletter \\
\hline 10 & David Suzuki Foundation (DSF) & $\begin{array}{l}\text { All Over the Map } 2006 \text { (Ontario } \\
\text { Section) }\end{array}$ & 2006 & Report \\
\hline 11 & $\begin{array}{l}\text { International Institute of Concern for } \\
\text { Public Health (IICPH) }\end{array}$ & Amazing Dr. Helen Caldicott & 2009 & News Report \\
\hline 12 & Greenpeace Canada (GPC) & $\begin{array}{l}\text { Greenpeace Canada Annual Review } \\
2008\end{array}$ & 2008 & Report \\
\hline 13 & Ontario Clean Air Alliance (OCAA) & Powerful Options & 2009 & Report \\
\hline 14 & Pollution Probe & $\begin{array}{l}\text { RE: Ontario Power Authority Stuply } \\
\text { Mix Advice Report }\end{array}$ & 2006 & Summary \\
\hline
\end{tabular}

5 Although there is no date explicitly mentioned on the report, it contains no citations for documents published after 1999. Coupled with the visual style of the report, it appears to be a pre-2001 document. 
Next, the overall stance on nuclear power and climate change from the pre-2001 era text was compared with the ENGO's stance for the recent era text. The changes or consistencies between the stances of each era were texted. As well, the texts from both eras were compared to the interview discussions by the ENGO's KI, and the differences or consistencies between the interview results and the textual analysis results were documented.

Twenty texts in total were analyzed, two from each of the eligible eight ENGOs plus four from the deviant case ENGO.

Once the results of the analysis were summarized into tables, an odds ratio was calculated for pre-renaissance vs. post-renaissance positions. Two odds ratios were calculated, one for the non-deviant ENGOs and the other for the deviant case, EP. The odds ratio was defined as the ratio of negative mentions of nuclear power to non-negative (i.e., neutral plus positive) mentions of nuclear power.

\section{PRUPERTY OF \\ RYERSON UNIVERSTTY LIBRARY}




\section{5-0: RESULTS}

\section{5-1: INTERVIEW RESULTS}

Where appropriate, quotes from the KIs have been included here. After each quote, a short code appears in parentheses, this refers to the number of the participant who supplied the quote; for example (S006) indicates that the preceding quote was furnished by sixth participant to be interviewed.

First, the interviewer set out to determine the importance of climate change relative to other environmental problems in the KIs' minds. Opinions on ACC were important because of the link between climate change and the resurgence of interest in nuclear power. If KIs were not concerned about ACC, then the lower-than-coal emissions of nuclear power plants would be of no interest to ENGOs.

KIs were asked what came to mind when they thought of the word "pollution", or how they would define "pollution". Only four respondents named GHGs specifically. However, other related responses included "dirty coal plants" (which produce large amounts of GHGs), "air pollution", "air quality" and "substances that have a negative impact on people and the environment". Airborne pollutants of different kinds were mentioned by ten respondents $(62 \%)$. As GHGs are airborne pollutants, this would indicate that KIs may have considered GHGs to be important pollutants.

KIs were also asked to name their current "number one" environmental concern. In response to this question, fourteen of fifteen respondents named climate change as their leading concern. Said one participant: 
Climate change is the direst [sic] thing that will hit this planet and so I would say that if we could look at the way we consume and drive our cars and heat our houses and change that then we could make a difference. (S003)

Another participant tied the growth of nuclear power to climate change. This participant was concerned that nuclear would be used as a tool to address $\mathrm{CO}_{2}$ reductions:

[My number one concerns are] climate change and the fact that nuclear power may be promoted in the name of fixing climate change. ( $(\mathrm{S} 007)$

Only one participant named another concern - "species loss, or sustainability". This participant elaborated, mentioning that they were a self-identified ACC "denier", sceptical about $\mathrm{CO}_{2}$ 's role in the current warming pattern. As a point of interest, this participant's denunciations of nuclear power were no less vehement because of his climate change scepticism.

The respondents were also asked to give their opinion of the "most promising" methods of generating electrical power. The researcher was curious to see if any respondents would say that they approved of nuclear power, and what kinds of technologies they supported if nuclear was untenable in their opinion. Not one respondent out of fifteen said that they considered nuclear power to be a preferred technology. Technologies falling under the umbrella of "renewable" had the most support; only one respondent mentioned a non-renewable technology, which was natural gas.

The topics of conservation and/or energy efficiency were mentioned by five KIs in answers to the question: "everyone agrees that efficiency is the most cost effective way [to increase net electricity output]" (S001). As well as promoting "green" energy and energy efficiency, KIs often mentioned imposing costs per unit of GHG from electricity generation as a way of providing incentives for the switch from fossil fuel to renewables: "costs [of renewable technologies] are very competitive, especially against something like nuclear and if you put a 
price on GHG emissions" (S002). ENGO employees tended to support first conserving the current supply of electricity through efficiency measures, then expanding renewables while removing fossil and nuclear generation.

Only one participant, in response to a similar question, suggested that nuclear should be part of the supply mix. As well, this participant felt that since the power plants were already constructed, the greatest part of the damage had already been done in the construction phase, and to let the plants live out their useful lives would be less wasteful than immediately decommissioning them:

We should just not replace it [with more nuclear power] and let it die off natural death... [A]t the same time [our non-ENGO parent] organization supports refurbishment. In defence of the power workers...we have to keep people's jobs and keep the economy going and represent the worker's best interests until we can make that transition to renewable energy (S014).

Three other KIs felt that for the time being, nuclear was certain to remain in place at least until the existing plants required refurbishment. "[Nuclear power] is not sustainable, but it could be conceived as a stopgap... [it] might be considered the lesser of two evils right now" (S016) and "there will be a lot of time before nukes can be brought down, depending on how quickly we can get more into demand management and the renewables" ( $\mathrm{S} 005$ ) were the somewhat fatalistic sentiments of two of the three aforementioned KIs. Another participant summed up: "We're not saying shut the existing ones down tomorrow, we're saying don't make huge capital investments to rebuild existing ones" (S001).

All respondents were asked if they agreed that nuclear power was a controversial issue in Canada. Of those asked, all but one respondent (who declined to answer) felt that nuclear power was controversial. Safety was the most-cited source of controversy, followed by economics or 
cost and waste disposal concerns. As well, six KIs felt that government support of nuclear power was a violation of public trust:

People are inclined to trust the government; it's a breach of trust that the government would put the public at risk here. Just look how long it took for people to take chemical pollution seriously - a big part of that delay was that industry and government were not interested in discussing the risks (S010).

Concern about abuse of trust by governments and industry was mentioned 12 times. In particular, advertisements for the nuclear industry were mentioned by two KIs, included below:

The advertising that the nuclear industry is putting out is totally misleading. [The public] just hears about the power generation part of it without knowing the consequences...it's like selling medication without listing the side effects (S003),

and:

There's a very sophisticated ad campaign for nuclear, they're blanketing the TV, the radio, the newspaper... when there's a loss of 600 jobs from Nanticoke coal plant and another 700 from Lake Erie Steel, and they're dangling 1000 jobs in front of you... (S009).

One participant was highly critical of the centralized decision making that lead to choosing nuclear power in the first place. This participant and two others were in favour of freemarket oriented policies in order to reduce government's capacity to fund projects such as nuclear power plants:

I have zero confidence that we will choose wisely among technologies because we have foolish ways of reaching those decisions...the reigning paradigm in this country is one of central control. If this was about the supply of digital audio players [or] whatever else there might be there would be a very different set of assumptions being made. It would be about where you think the smart money is going to go, and willing investors, and willing consumers.

[But] when we're talking electricity, suddenly we're in the realm of the Ontario Power Authority, and the OEB, and the Ontario government; we're in a world where we can't even get time to have a hearing, let alone to build a 
reactor and have it pay off its mortgage. That's the proof that it doesn't work! It's that we can't even pretend we have the same framework of inputs and outputs long enough to get a hearing finished (S006).

Two KIs mentioned that scrapping the Nuclear Liability Act and forcing operators to assume the full risks of their investments would automatically rule out nuclear power in the short term. The other side of that coin, according to on of the KIs, is that

If we had private investors willing to invest [and assume the risks], then a lot of my concerns would be allayed [because the risks and costs would have had to be sufficiently lowered to make it an attractive investment] (S006).

Lobbying by the nuclear industry was generally frowned upon and was considered a betrayal of trust by four KIs. One KI explained that

Murray Elston [from Ontario's 1985-1990 Peterson government] is now the head lobbyist for the Canadian Nuclear Association. But I wonder if there's going to be some undue influence in this current government from a guy with the same party affiliation (S012).

The government perspective on nuclear power was also addressed. KIs were asked to speculate on why governments in Canada were willing to invest in nuclear power. While speculation may not be the most informative way to discover the governments' motives, having the KIs comment on what they perceived to be the governments' motives enlightened this research. It allowed the researcher to find out what ENGO employees perceived to be their challenges in the battle of ideas that is being fought over nuclear power.

For example, four KIs thought that nuclear power's main advantage was that it was a familiar technology and that despite its flaws and public concern over its safety and cost, it would remain attractive because politicians were familiar with it. Five KIs re-iterated that they believed that governments were being influenced by a strong pro-nuclear lobby, or that governments were naive about the risks and benefits of nuclear vs. "renewable" energy. 
Respondents were often specifically opposed to nuclear power, though their opposition was sometimes more pragmatic rather than a part of a fundamental "belief system". Four respondents specifically mentioned that their opposition to nuclear power was in fact opposition to certain issues that the nuclear industry could possibly resolve; these KIs would conceivably support nuclear power if, for example, costs were lowered, safety was improved or security concerns addressed. Only five KIs mentioned that they were opposed to nuclear power in broad terms. Three respondents mentioned that they had no position on nuclear power per se-but due to the impacts that nuclear power has on the human and non-human environment, they found themselves unable to support it.

For example, one participant related that nuclear's "immense opportunity cost" in terms of grid space and resources precluded his organization's support because it would effectively stop meaningful investment in renewables. One KI focused on the impacts of mining, saying:

We have a policy on uranium mining. We feel that if there is no uranium mining, then there is no nuclear power or weapons so those problems are nipped in the bud (S011).

Each participant was asked if their organization's position on nuclear power had changed over the past fifteen years (the time interval of this study). Of fifteen respondents, none said that their organization's stance had changed or become pro-nuclear in the past fifteen years. One respondent replied: "only the intensity of our opposition has changed, when nuclear power is proposed and promoted we become more active; when interest drops off, so does our activity" (S007). And from another respondent: "The specifics may have changed, but we've always been anti-nuclear" (S008). This question brought up interesting answers - each KI answered this question in the negative, as in "no, our organization has not changed its opinions on nuclear power"; however, seven KIs then went on to say that some aspect of their opposition was 
different now than it was fifteen years ago. The common thread for all responses was that of the KIs that were opposed to nuclear power fifteen years ago, all were still opposed to nuclear power at the time of the interview. The researcher believes that a greater exploration of this tendency of apparent contradiction may be worth exploring further in future studies.

The opinions of eight of the KIs had remained entirely consistent over the 15 year interval. Four others responded that they had grown more opposed to nuclear power. One respondent from a smaller organization explained that "we tried to be a neutral group, but we've changed and now we're definitely against [nuclear power]" (S009). The remaining four KIs said they were still opposed to nuclear power, but had changed the intensity of their opposition. Said one respondent, "I don't want to leave the impression that we've really warmed up to it; it has changed from...100\% against to $99 \%$ [against]" (S016).

Ten of the KIs claimed that the memberships of their organizations would be opposed to nuclear power, even if it were presented as a tool to mitigate climate change. Respondents commonly said that members of their organizations would be familiar with the practices that the organization supports and condemns and would support the organization's viewpoints. Four respondents felt that some members of the general public might be swayed by the "nuclear industry's public relations" campaign, but felt that their membership would be immune to such arguments (S006). Five KIs were unsure about their membership's opinions, and only one felt that some of their membership would accept nuclear power in the short term.

None of the KIs had data on their membership's opinions, instead they had to speculate. Regardless, the researcher felt that the KIs' familiarity with their organization and their constituents make those speculations valid. ENGOs are in communication with their members ENGOs are constantly sending leaflets, updates and notices to their members. While this 
communication is more or less one-way, ENGOs' members can still provide feedback on ENGO decisions and actions. For example, if an ENGO was to come out and publicly endorse the seal hunt, some members may threaten to cancel their membership or withhold funding unless the position was reversed. So, the KIs' viewpoints on their membership should be considered valid because the opinions of their membership have a bearing on the organization's legitimacy.

All respondents were asked felt that Canadian governments should be doing more to supply and conserve electricity. Not one respondent felt that the federal government was doing a satisfactory job, and only one respondent felt that the provincial government was doing a suitable job. Some respondents felt that the Green Energy Act was a "good start" but wanted to see more action. All KIs agreed that governments were in general failing by not supporting green energy enough.

Two respondents thought that Canadian governments were doing better than they were years ago, but still not good enough. Ten respondents also mentioned that they would like to see more focus on efficiency and conservation measures instead of new capacity; in total, there were eighteen separate references to efficiency or conservation in the interviews.

Each participant was asked to explain how they would influence policy if they were given the power to do so. The respondents tended to start with the failings of governments and address those issues first. Twelve of the respondents said that, given the opportunity, they would increase funding for renewable energy and efficiency measures. Several KIs wished to stop subsidizing nuclear power and to disallow the passing of cost overruns onto consumers. Reasons for these actions included:

- speed of deployment: "renewable energy can be brought online pretty quickly compared to other options" (S003); 
- moving to a more resilient community-based system: "if climate change is going to bring more extreme weather, that will put our distribution system at risk and we will have to either look at our design standards or look at going to a community based system that doesn't require a large distribution network" (S005);

- making room for green options "When you build lots of nuclear into the system the space for other options gets really small" (S002) and lowered costs "There's a huge conservation potential and [conservation is] the cheapest way of meeting our energy needs" (S007).

Furthermore, two out of the fifteen of the respondents said they would put a cap on, or otherwise legislate a reduction in greenhouse gas emissions.

All KIs were asked if they knew of any other ENGO that had changed its stance from anti-nuclear to pro-nuclear - no respondents could think of any organization that had changed its mind in that way. As one participant phrased it, "as long as I've been in the business, 30 years, ENGOs have been opposed to nuclear power and I don't see any changes" (S001).

To determine if they might change the positions, KIs were also asked if they could provide any reasons that might change their opinions on nuclear power. This question was phrased as "If you could change anything about nuclear power to make it attractive enough to use, what would those changes be, and what would your version of that look like?". Six respondents could conceive of situations where nuclear power would be appropriate; that if certain aspects were changed, they could possibly support the technology. For example, in the words of one respondent: "If they turned around and said that they could produce a nuclear power plant that was very efficient, safe, could meet all of its timelines and targets and was cost effective, then that would make me take a closer look at nuclear (S005). 
Ten KIs were not willing to entertain even a hypothetical improvement of nuclear power. One KI, when asked what would make nuclear attractive, responded that the only way to take care of all of the negatives would be to "put it on the moon" (S014).

KIs were also asked to comment on whether the arrival of climate change had made them consider supporting nuclear power. All responses were negative - every $\mathrm{KI}$ responded that there has been nothing to make them consider supporting nuclear power. Overall, the sentiment was that the existing nuclear power infrastructure was somewhat acceptable for the moment, as long as no new investments were made that would detract from investments into green or renewable energy or conservation measures. In effect, this meant that no investment in nuclear power was acceptable unless it was the only way to reduce GHG emissions - and fifteen KIs were clear that they believed that this was not currently the case:

There's only so much capital, time, skill, money, expertise and resources available to us. And if we invest in nuclear that's money that we can't get back (S008).

One KI made it clear that it was the lesser of two evils in terms of emissions, at least compared to coal, and that rather than say "no nuclear power anywhere, anytime" a more reasonable approach would be to evaluate the merits of each case individually; "I guess [ACC] is the lens through which we're seeing our current energy positions" (S016).

As well, there were three final questions about the KIs themselves, asking their age, educational and work background and whether they received a salary or not (See Appendix A for the questions). Responses to each of these three demographic questions were diverse. A total of eight different professions were mentioned, with several KIs identifying themselves as more than one profession (i.e. "retired activist" or "activist by avocation, economist by training"). The age ranges of the KIs were also diverse, with at least one KI from each age range. Finally, there was 
an equal split between salaried employees and non-salaried volunteers, with seven KIs identifying themselves as belonging to either category (two KIs declined to answer). However, the content from these questions does not help to resolve the objective of this study, so these data were compiled but no further action was taken in regard to it.

\section{5-2: TEXT ANALYSIS RESULTS}

Although very different sources were used for the textual analysis, it does not invalidate the analysis because the results are clear and consistent from one kind of source to the next. In tables 3 and 4 one can see the remarkable consistency in the way that positions on nuclear power was expressed in all of the documents.

A summary of the analysis of texts from Energy Probe (EP) can be found in table 3. EP made a total of 72 references to nuclear power in its four texts, 10 of which were neutral and 62 of which were negative. See table 4 for a summary of the results of the analysis on EP's texts. 26 references were from the pre-2001 and 46 from the post-2001 sub-period. In the pre-2001 sub-period, one of these references was neutral; however, the remaining twenty-five references were negative towards nuclear power. In the post-2001 sub-period, 9 references were neutral; the remaining 37 were negative towards nuclear power. EP did not make any positive connections to nuclear power in the selected texts.

A summary of the results can be found below, in table 5. There were a total of 101 occurrences of the Climate Change Indicator Words (CCIWs) in the sixteen texts; 76 in the pre2001 texts and 25 from the post-2001 texts. There were no CCIWs at all in the four EP texts. None of the organizations made a positive connection between nuclear power and climate change mitigation in either era. 
Table 3: Analysis of Energy Probe's four texts

\begin{tabular}{|c|c|c|c|c|c|c|c|c|}
\hline \multirow{3}{*}{$\#$} & \multirow{3}{*}{ Name of Energy Probe Text } & \multirow{3}{*}{ Citation } & \multicolumn{6}{|c|}{ Number of References to: } \\
\hline & & & \multicolumn{2}{|c|}{$\begin{array}{l}\text { Climate Change } \\
\text { Indicator Words }\end{array}$} & \multicolumn{4}{|c|}{ "Nuclear" } \\
\hline & & & $\begin{array}{c}\text { All } \\
\text { References }\end{array}$ & $\begin{array}{c}\text { Pro- } \\
\text { Nuclear } \\
\text { References }\end{array}$ & $\begin{array}{c}\text { All } \\
\text { Refs }\end{array}$ & $\begin{array}{l}\text { Neutral } \\
\text { Refs }\end{array}$ & $\begin{array}{l}\text { +ve } \\
\text { Refs }\end{array}$ & $\begin{array}{l}\text {-ve } \\
\text { Refs }\end{array}$ \\
\hline 1 & Re-Defeat the Nuclear Industry & $\begin{array}{l}\text { Adams, } \\
2005\end{array}$ & 0 & 0 & 22 & 0 & 0 & 22 \\
\hline 2 & $\begin{array}{l}\text { The Two Blows that Killed the } \\
\text { Industry }\end{array}$ & $\begin{array}{l}\text { Solomon, } \\
2009 a\end{array}$ & 0 & 0 & 24 & 9 & 0 & 15 \\
\hline 3 & CANDU Flawed & $\begin{array}{l}\text { Nichols, } \\
1997\end{array}$ & 0 & 0 & 13 & 0 & 0 & 13 \\
\hline 4 & $\begin{array}{l}\text { Energy Probe's } 1997 \\
\text { Accomplishments }\end{array}$ & $\begin{array}{l}\text { Energy } \\
\text { Probe. } \\
1997\end{array}$ & 0 & 0 & 13 & 1 & 0 & 12 \\
\hline & TOTALS & & 0 & 0 & 72 & 10 & 0 & 62 \\
\hline & PERCENTAGE & & & $0.0 \%$ & & $13.9 \%$ & $0.0 \%$ & $86.1 \%$ \\
\hline
\end{tabular}

None of the remaining organizations made positive mentions of nuclear power in regards to climate change. See table 5 for a summary of the analysis. Assuming that the texts represented the accepted position of each ENGO at the time of publication, and between publications there were no extreme shifts in position, it may be said that the organizations were overall not positively disposed to nuclear power either pre-2001 or post-2001, at least as far back as the oldest available text from each organization. This assertion is valid because for every organization except for Pollution Probe there were no positive references to nuclear power. The 2006 Pollution Probe text had two mentions of nuclear power that were positive, but twelve that were negative. Overall it seemed that Pollution Probe's position was negative. EP's climate change scepticism did not seem to predispose the organization to nuclear power any more than the other organizations' concern about climate change; all organizations were on the whole more negative than neutral, and never positive, about nuclear power. 
Table 4: Text analysis results for the sixteen texts from the eight cligible ENGOs

\begin{tabular}{|c|c|c|c|c|c|c|c|c|}
\hline \multirow[t]{3}{*}{$\#$} & \multirow[t]{3}{*}{ Organization } & \multirow[t]{3}{*}{ Citation } & \multicolumn{6}{|c|}{ Number of References to: } \\
\hline & & & \multicolumn{2}{|c|}{$\begin{array}{c}\text { Climate Change Indicator } \\
\text { Words }\end{array}$} & \multicolumn{4}{|c|}{ "Nuclear" } \\
\hline & & & $\begin{array}{c}\text { All } \\
\text { References }\end{array}$ & $\begin{array}{l}\text { Pro-Nuclear } \\
\text { References }\end{array}$ & All Refs & $\begin{array}{c}\text { Neutral } \\
\text { Refs }\end{array}$ & $\begin{array}{l}\text { +ve } \\
\text { Refs }\end{array}$ & $\begin{array}{l}\text {-ve } \\
\text { Refs }\end{array}$ \\
\hline 1 & $\begin{array}{l}\text { Citizens' Environmental Alliance of } \\
\text { South Western Ontario (CEASWO) }\end{array}$ & $\begin{array}{l}\text { CEASWO, } \\
2001 \\
\end{array}$ & 4 & 0 & 1 & 0 & 0 & 1 \\
\hline 2 & Citizens for Renewable Energy (CFRE) & CFRE, 1997 & 2 & 0 & 5 & 3 & 0 & 2 \\
\hline 5 & Greenpeace Canada (GPC) & May, 1989 & 0 & 0 & 55 & 22 & 0 & 33 \\
\hline 6 & Ontario Clean Air Alliance (OCAA) & OCAA, 1999 & 1 & 0 & 3 & 2 & 0 & 1 \\
\hline 7 & Pollution Probe (PP) & $\begin{array}{l}\text { McMullan, } \\
1976\end{array}$ & 0 & 0 & 134 & 49 & 0 & 85 \\
\hline 8 & $\begin{array}{l}\text { Citizens' Environmental Alliance of } \\
\text { South Western Ontario }\end{array}$ & $\begin{array}{l}\text { CEASWO, } \\
2009\end{array}$ & 0 & 0 & 9 & 5 & 0 & 4 \\
\hline 11 & $\begin{array}{l}\text { International Institute of Concern for } \\
\text { Public Health }\end{array}$ & IICPH, 2009 & 1 & 0 & 8 & 0 & 0 & 8 \\
\hline 12 & Greenpeace Canada & GPC, 2008 & 6 & 0 & 5 & 1 & 0 & 4 \\
\hline 13 & Ontario Clean Air Alliance & OCAA, $2009 \mathrm{C}$ & 0 & 0 & 44 & 14 & 0 & 30 \\
\hline 14 & Pollution Probe & PP, 2006 & 1 & 0 & 15 & 1 & 2 & 12 \\
\hline & TOTALS (w/o Energy Probe) & & 101 & $\mathbf{0}$ & 361 & 125 & 2 & 234 \\
\hline & PERCENTAGE (w/o Energy Probe) & & & $0.00 \%$ & & $34.6 \%$ & $0.6 \%$ & $64.8 \%$ \\
\hline
\end{tabular}


As mentioned in the Methods Section, an odds ratio was calculated for EP and the remaining ENGOs. The ratio was calculated as follows. In the pre-renaissance period, the nondeviant (ND) ENGOs made a total of 157 negative references to nuclear power and 337 nonnegative references (i.e., neutral plus positive references) to nuclear power, while the deviant ENGO Energy Probe (EP) made a total of 1 non-negative reference and 25 negative references. Thus, in the pre-renaissance period, the odds of a ND ENGO making a non-negative reference to nuclear power were 337:157 $=2.1464$. In the same period, the odds of EP making a nonnegative reference to nuclear power were 1:25 $=0.04$. In the post-renaissance period, the ND ENGOs made a total of 96 negative references to nuclear power and 176 non-negative references to nuclear power, while EP made a total of 9 non-negative reference and 37 negative references. Thus, in the post-renaissance period, the odds of a ND ENGO making a non-negative reference to nuclear power were $176: 96=1.8333$. In the same period, the odds of EP making a nonnegative reference to nuclear power were $9: 37=0.2432$. See table 5 for a summary of these results.

Table 5: The odds of the deviant and non-deviant ENGOs making non-negative references to nuclear power in pre- and post-renaissance periods

\begin{tabular}{|l|c|c|c|}
\hline & $\begin{array}{l}\text { Non-Negative } \\
\text { References to } \\
\text { Nuclear Power }\end{array}$ & $\begin{array}{c}\text { Negative References } \\
\text { to Nuclear Power }\end{array}$ & $\begin{array}{c}\text { Odds of a Non- } \\
\text { Negative: Negative } \\
\text { Reference }\end{array}$ \\
\hline $\begin{array}{l}\text { Non-Deviant ENGOs } \\
\text { (pre-2001) }\end{array}$ & 337 & 157 & $2.1464: 1$ \\
\hline $\begin{array}{l}\text { Non-Deviant ENGOs } \\
\text { (post-2001) }\end{array}$ & 176 & 96 & $1.8333: 1$ \\
\hline $\begin{array}{l}\text { Deviant ENGO (pre- } \\
\text { 2001) }\end{array}$ & 1 & 25 & $1: 25$ \\
\hline $\begin{array}{l}\text { Deviant ENGO (post- } \\
\text { 2001) }\end{array}$ & 9 & 37 & $1: 4.1111$ \\
\hline
\end{tabular}


Odds ratios were calculated for both the deviant ENGO and the ND ENGOs. The odds ratio for the ND ENGOs was calculated by the following calculation:

(post-2001 non-negative references) / (post-2001 negative references)

\begin{tabular}{c}
$\begin{array}{c}\text { (pre-2001 non-negative references) } / \text { (pre-2001 negative references) } \\
=\end{array}$ \\
(post-2001 non-negative references) $*($ pre-2001 negative references) \\
\hline (pre-2001 non-negative references) $*$ (post-2001 negative references) \\
$\begin{array}{c}(176) *(157) \\
(337) *(96)\end{array}$ \\
$=\mathbf{0 . 8 5 4 1}$
\end{tabular}

Thus, the odds of a ND ENGO making a non-negative reference in the post-renaissance period are $0.8541: 1$, which means there are very low odds that one of the ND ENGOs will make more non-negative references to nuclear power in the post-renaissance period than in the pre-renaissance period. This might suggest that ND ENGOs were in fact less likely to reference nuclear power in a non-negative light in the latter period

For the deviant ENGO, a similar calculation was made. The following calculations show how the odds ratio was arrived at:

(post-2001 non-negative references) / (post-2001 negative references)

(pre-2001 non-negative references) / (pre-2001 negative references) $=$

(post-2001 non-negative references) $*$ (pre-2001 negative references)

(pre-2001 non-negative references) * (post-2001 negative references) $=$

(9) * (25)

$(1)^{*}(37)$

$=\mathbf{6 . 0 8 1 1}$ 
Thus, the odds of the deviant ENGO making a non-negative reference in the postrenaissance period are 6.0811 , which is a substantial difference. This ratio suggests that the odds that EP would make a non-negative reference to nuclear power in the post-renaissance period were more than six times higher than in the pre-renaissance period. This could suggest that EP might have softened its stance towards nuclear power, at least inasmuch as it was making relatively more neutral references than negative references to nuclear power in the latter period (EP made no positive references to nuclear power in either period). 


\section{6-0: CONCLUSION}

The results described in Section 5 would seem to answer the research questions with a tentative "no", however there are serious reservations about the kinds of conclusions that this study may offer. It is more accurate to say that the ENGOs that were examined in this study were very much against the use of nuclear power as a "climate-friendly" energy source.

However, more than one KI mentioned that their anti-nuclear stance had changed over time, one of whom mentioned that " ...[ACC] is the lens through which we're seeing our current energy positions", implying that there might have been some softening in the stance of that particular ENGO vis-à-vis nuclear power.

Text analysis revealed some interesting findings. For example, EP's odds ratio indicated that that organization was apparently six times more likely to refer to nuclear power in a nonnegative way in recent documents compared to pre-renaissance documents. This could mean that EP has made a shift in its position on nuclear power to become more neutral since 2001 (it did not appear to become more positive, there were still no positive references to nuclear power in any of EP's texts). The odds ratio of the ND ENGOs indicated the opposite; that they would be less likely to make positive or neutral statements in the post-2001 period. These findings aligned with the results of the interview transcription analysis.

A more general conclusion about the state of Canadian ENGOs as a whole would be inappropriate in the light of the analysis that was done here.

The fifteen KIs disagreed with the assertion that nuclear power was a useful tool for fighting climate change. Some KIs were more prone to being anti-nuclear, as in they opposed all investments in nuclear power and nuclear technology; some others asserted that they had no 
official stance on nuclear power per se but said that they had not seen any nuclear proposals that they could endorse or otherwise approve of (even off the record). KIs involved in this study typically cited safety, cost (both opportunity cost and dollar cost), waste disposal, proliferation and the link between civilian and military applications of nuclear power, and the environmental concerns around plant construction and uranium mining and milling as reasons why they could not support it.

Fifteen of the KIs that were interviewed for this project agreed that climate change was the most important environmental issue today, and KIs' preferred electricity generation technologies tended towards low- or no-carbon technologies such as small-scale hydroelectric, wind and solar power. However, despite fission's zero carbon output, none of the respondents cited nuclear power as a "preferred" technology.

KIs generally agreed that nuclear power probably would play a role in the future of Ontario's energy supply given the large amount of installed nuclear generating capacity. The respondents were being realistic in saying that because a great deal of Ontario's electricity comes from nuclear power plants, until those plants become inoperable there will likely be a place for nuclear power on Ontario's grid, whether they would prefer it or not. Most KIs were willing to accept the continued operation of some of the already-existing reactors for the short term while conservation and renewable energy programs could be fully invested in.

Different views on the importance of climate change as an environmental problem did not seem to influence positions on nuclear power. The organization EP, which is sceptical of some of the science behind the theory of $\mathrm{ACC}$, did not make positive references to nuclear power at all in the four texts that were examined, and $86.1 \%$ of all of the EP texts' references to nuclear power were negative. The remaining organizations all of which embrace the idea of ACC were 
also overtly negative towards nuclear power. Over ninety-nine percent of all of these articles' references to nuclear power in the fourteen texts were negative or neutral about nuclear power and less than one percent of the mentions were positive.

The results of the textual analysis are in agreement with the results of the interview with each organization's respective KI. Each organization appears to have the same general position (i.e., of opposition) to nuclear power in Ontario. Specifically, none of the texts identified nuclear power as being an acceptable method of cutting carbon emissions or otherwise addressing climate change. Finally, the broad sentiment regarding nuclear power in the texts was uniformly and overwhelmingly negative.

At the beginning of this text, two questions were posed: "Are Canadian ENGOs less opposed to the use of nuclear power in Ontario after 2001 compared to before 2001"; and "To what extent is any change in opposition due to nuclear fission's negligible GHG emissions?". There is some evidence that some of the ENGOs studied here have in fact softened their stance on nuclear power slightly to become less negatively disposed to the technology if not more positively disposed. To be clear, this analysis revealed evidence that two of the fourteen ENGOs may have become more neutral in their treatment of nuclear power. One of these ENGOs, EP, had a KI from the organization that was still staunchly opposed to nuclear power but the text analysis indicated that there was a distinct shift over time to an increased prevalence of nonnegative references to nuclear power. The other ENGO was not eligible for text analysis, but that ENGOs' KI revealed in the interview that their organization had shifted to a slightly more neutral stance from approximately ten years prior. As well, that KI indicated that the increased importance climate change was playing in policy circles was partly responsible for that shift. Therefore, in response to the second question posed for this study, at least one KI's perceived 
shift in their organization's position can be traced to climate change and the reduced GHG emissions produced by nuclear power.

Could EP's apparent shift also be a result of climate change? This seems unlikely, as they meet arguments for decisive action on climate change action with scepticism. From EP's own documents, it is apparent that they view nuclear power as undesirable in the extreme. They also assert that the actions to address climate change suggested by the IPCC will have severe economic and ecological consequences. Furthermore EP is clear in its message that the climate is changing and humans may have played a small role in that change but not enough to justify an immediate and massive reorganization of the way people consume energy. Given this position, this researcher must conclude that EPs position on nuclear power did not likely shift due to supposed benefits regarding $\mathrm{CO} 2$ emission reductions. 


\section{7-0: DISCUSSION}

The expectations of the researcher going into the study should be explained. It is customary for researchers using qualitative methods to note their thoughts on their subject before they commence their study. This allows the researcher to look back at their a priori position to see if they have changed their mind on the subject. As well, it provides a touchstone for the readers of the study to gauge the potential for biases and so forth that the researcher would have brought to the work.

This researcher initially felt that nuclear power was a poor choice for Ontario's electricity system. I felt that nuclear power was not reliable, efficient, environmentally responsible or economical. In short, the researcher was "against" nuclear power development in Ontario. This likely biased the study in several ways. For instance, the researcher identified strongly with KIs' in general. To that effect, the researcher may have occasionally given cues to the KIs to elicit certain desired responses in order to affirm the researcher's own personal beliefs. To put another way, the researcher may have "smiled with his voice" when KIs provided answers that fit with the researcher's views, and "frowned with his voice" when KIs did otherwise. This kind of interaction is more or less unavoidable in an interview, but it serves the study well to identify such biases clearly.

There were numerous weaknesses in this study, some of which were able to be addressed, and others which were more systemic and will have to be thought of as "lessons learned".

First, the determination of the study period in Section 4-5 was somewhat arbitrary. While the WNA is a fairly reputable organization, to base the cut-off period for this study on this kind of an assertion by any organization seems disconnected from the true purpose of the study. The meaning of the year 2001 in the history of nuclear power is somewhat questionable, and other 
sources may dispute the year that the nuclear renaissance began. The usefulness of that date in this study was tied to the facts that it was a single moment that could divide history into "before and after" and that the organization that supported that date as the start of the renaissance could be considered something of an authority on the subject of nuclear power.

Second, the interview process was fundamentally flawed from the beginning. The methodology of the interview process was unclear and ill-defined at the beginning, and the questionnaire was poorly designed. The way that the interview process progressed, the researcher found that it was difficult to make useful, credible conclusions from the data that was generated. The researcher had no plan for finding out why some potential KIs declined participation in the study; as well, there was no allowance for finding out how those organizations whose employees declined participation differed from those who agreed to participate. Such information would have helped to show if the findings of this study could be more generally applied to ENGOs as a whole, or two certain groups or kinds of ENGOs and so on. As well, significant skill is required when using generated as opposed to existing data in qualitative research (Mason, 2002) and given the skill level of the researcher a less demanding subject matter would have been preferable. As it stands, it is difficult to make credible assertions as to the generalizability of this study's findings.

There may also be bias generated by the inclusion of more than one KI from each large ENGO as opposed to only one from each small ENGO. As described in the Methods Section, this was done because in small organizations the portfolio of climate change, energy and or nuclear power was often handled by one individual, while in large organizations those three concerns were often divided among multiple individuals. Despite the valid reason for seeking 
out more than one individual from the larger organizations, it did mean that larger organizations were perhaps over-represented.

One inconsistency in the textual analysis that deserves mention is the use of four texts from the deviant case versus two texts from every other ENGO. While the reasons for this are laid out in Section 4-8 it still represents an inconsistency in the method that the researcher would have preferred to rectify for the sake of consistency alone. That said, the effect of the extra texts may have in the final analysis is likely to be minimal due to the fact that the position of each ENGO is established by aggregating the keyword mentions into pre- and post-renaissance states.

If the study was to be re-designed, there are several things that could be done to further strengthen the legitimacy of the conclusions. First, a much smaller group of ENGOs would probably have been more practical and more fertile. As Silverman (2000) asserts, qualitative research is best used to say a lot about a little, rather than a little about a lot. With a smaller sample, more texts could have been found and analyzed in more ways to give a richer body of data to work with.

Second, the textual analysis would have better served the study if it had been done before the interview process. In hindsight, a better design would have been to choose two or three ENGOs to study then find as many texts as possible from the ENGO or perhaps from third parties such as newspapers. Following analysis of the texts, individuals affiliated with the ENGO either as employees or volunteers could be contacted to recruit potential informants, some of which may be useful in validating the analysis of the researcher as per Crabtree and Miller (1992:86). Finally, a stronger theoretical basis, both in qualitative methods and in the theory of power relations in society would perhaps help to allow a greater generalization of the 
conclusions of a redesigned study. For example, following the methods for content analysis (Berg, 1989) closely would have resulted in a more robust study.

However, despite the weaknesses, there is ample opportunity for further research. Some potential research would address specific questions raised from this analysis, such as the potential shift in EP's position that may have been apparent from the odds ratio. Before concluding that a shift in EP's position has occurred or not, one must take into account the interview with the KI from EP, which did not show any indication of a possible shift in position. A broader text analysis of documents from EP should be done in order to help determine whether there has been a true and significant shift at EP, and to determine why that shift has occurred. As noted in the Conclusion, it seems unlikely that the shift has occurred because of the supposed low- $\mathrm{CO}_{2}$ emission qualities of nuclear power.

As for the other ENGO that appeared to shift its position, a closer examination of that organization should be performed in order to substantiate that shift. As this organization did not qualify for textual analysis under the method designed for this study, any new method should allow for the inclusion of this ENGO. Even though both objective questions were answered regarding this particular ENGO, more questions have arisen. Did this organization perhaps put more stock in the IPCC's interpretation of climate change than EP?

In terms of new studies, an examination of dissention in ENGOs could be another potential study. One of the reasons that the interviews were ineffective was that it was concerned with individual's opinions about their ENGO, and those opinions were originally assumed to be analogous to the ENGO's. While that assumption is highly debatable, it does bring up the following question: What happens to those ENGO employees that dissent from the ENGO's official stance? Are they forced out, or otherwise compelled to leave for other reasons? 
An examination of how institutions such as the larger ENGOs and their employees deal with dissent in the short and long term would be interesting and perhaps generalizable to other institutions.

It would also be interesting to compare ENGOs from different countries' positions on nuclear power and climate change. For example, how does ENGOs' nuclear policies in Germany, with an active and powerful environmental movement that is wary of nuclear power, compare to ENGOs' nuclear policies in France, a country that has most of its electricity generation tied up in nuclear power? 


\section{8-0: IMPLICATIONS}

Assuming the ENGOs involved in this study are typical, and given the involvement of ENGOs in the policy formation process in Canada and Ontario, there will likely continue to be conflicts over both the production of electricity using nuclear power and the siting of nuclear power plants in greenfield sites in Ontario. The weight of evidence that has been collected as for this project supports the idea that ENGOs have historically been opposed to nuclear power and will continue to oppose it in the future, despite any supposed benefits in terms of GHG emission reductions that may be sought through the use of this technology.

There is scholarly and anecdotal evidence that NGOs have been successful in influencing - some aspects of environmental policy formation, especially in the past few decades (Wapner, 2002). Internationally, agreements such as the Kyoto Protocol have been both championed and influenced by NGOs (David Suzuki Foundation, n.d.). In Canada, Bisphenol A (BPA) was recently banned, apparently due in large part to the influence of a group of ENGOs, including the campaign driven by the organization Environmental Defence (Foster, 2009). In Ontario, the Green Energy Act was largely influenced by ENGOs who were keen to incorporate policy tools that had been successful in other jurisdictions (CSRwire.ca, 2009; GEAA, 2009). However, there are no examples of NGOs having a definitive effect on nuclear policy in Canada. There are only two areas of nuclear policy that are open to NGOs, these being the environmental assessment process and the Nuclear Waste Management Organization hearings. Of course, until reactors are actually in the process of getting official approval, NGOs have no access to the levers of power. 
Successful lobbying efforts aside, there is much in Canadian environmental politics with which ENGOs are struggling with. Especially in Canadian environmental governance, environmental policies in resource-rich areas are often geared more towards expediting resource extraction than to mitigating environmental harms (Hessing et al., 2005). In these cases, ENGOs have had difficulties influencing what governments and key stakeholders have already decided upon. In other words, setting the agenda is a major challenge for environmental organizations in Canada, particularly in the field of energy resources (Hessing et al., 2005;). The findings of this project appear to be consistent with the suggestion that agenda setting as discussed in Hessing et al. (2005) is off-limits to ENGOs.

From the findings of this research project, it seems that some ENGOs are likely to continue to oppose nuclear programs in Ontario. The ENGOs consulted in this process show no support for claims of nuclear power's ability to address ACC. In their opinions, the obstacles to nuclear power's relevance to the climate change era of energy planning are many and are generally insurmountable in a realistic time frame. 


\section{9-0: REFERENCES}

AARP. (2009). AARP Responds to Health Reform Scare Tactics. July 24, 2009. Retrieved August 12, 2009, from

http://www.aarp.org/aarp/presscenter/pressrelease/articles/mccaughey_statement.html

Abalone Alliance. (n.d.). The Diablo Canyon Timeline. Retrieved January 6, 2010 from http://www.energy-net.org/01NUKE/DIABLO1.HTM

Adams, T. (2005). Re-Defeat the Nuclear Industry. January 20, 2005. Retrieved December 13, 2009 from http://energy.probeinternational.org/nuclear-power/nuclear-safety/re-defeat-thenuclear-industry

Allf, N. (2008). President's Message: The Changing Face of Law Practice in Nevada. Nevada Lawyer, May, 2008.

Anderson, G. (2007). Rapporteur's Report. November 8, 2007. Retrieved August 12, 2009, from http://www.wango.org/congress2007/report.aspx

- Associated Press. (2010). Text of Obama's State of the Union Address. Thursday, January 28, 2010.

Ballamingie, P. (2009). First Nations, ENGOs, and Ontario's Lands for Life Consultation Process. In L. Adkin (ed.), Environmental Conflict and Democracy in Canada (pp. 85-101). Vancouver: UBC Press.

Benzie, R. (2009). Nuclear Plan on Track, McGuinty Says. The Toronto Star, July 142009.

Berg, B. (1989). Qualitative Research Methods for the Social Sciences. Simon and Schuster, Needham Heights, Massachusetts

Betsill, M., \& Corell, E. (2001). NGO Influence in International Environment Negotiations: A Framework for Analysis. Global Environmental Politics, 1(4):65-85.

Bjorkbom, L. (1999). Negotiations over Transboundary Air Pollution: The Case of Europe. International Negotiation , 4(3): 389-410.

Brand, S. (2007): An Early Environmentalist, Embracing New 'Heresies'. The New York Times, February 272007.

Business Wire. (2007). AN INCONVENIENT TRUTH Publisher Rodale Congratulates Former Vice President Al Gore on His Oscar. Retrieved February 4, 2010 from $\mathrm{http}: / /$ findarticles.com/p/articles/mi_m0EIN/is_2007_Feb_26/ai_n27305496/?tag=content;coll 
Campbell, R. (1989). Give Global Warming the Acid Rain Test; Go to Nuclear Power (Editorial). The New York Times, November 21, 1989.

Cashore, B. (2002). Legitimacy and the Privatization of Environmental Governance: How NonState Market-Driven (NSMD) Governance Systems Gain Rule-Making Authority. Governance, 15(4):503-529.

Chacon, L. (2009). Stewart Brand is Rethinking Nuclear. Retrieved September 2, 2009, from http://www.worldchanging.com/archives/009604.html

CEASWO. (2001). Citizens Environment Alliance Congratulates Herb Gray on Climate Change. June 30, 2001. Retrieved January 20, 2010 from

http://www.citizensenvironmentalliance.org/pressreleases/pr063001.html

CEASWO. (2009). Beyond Nuclear. April 13, 2009. Retrieved January 20, 2010 from http://www.citizensenvironmentalliance.org/pressreleases/Fermi\%20III\%20prsrelease\%2004_13 09.pdf

CFRE. (1997). From the Coordinator. June 1997. Retrieved January 20, 2010 from http://www.web.net/ cfre/Newsletters/news6.htm

CFRE. (2009). Plant a Solar Tree! September 2009. Retrieved January 20, 2010 from http://www.web.net/ cfre/Newsletters/news55.htm

Corell, E. \& Betsill, M. (2001). A Comparative Look at NGO Influence in International Environmental Negotiations: Desertification and Climate Change. Global Environmental Politics, 1(4):86-107.

Crabtree, B. \& Miller, W. (eds.). (1992). Doing Qualitative Research. Sage Publications, Newbury Park, California.

CSRwire.ca. (2009). Green Energy Act Alliance Endorses Minister Smitherman's Directive to Prioritize Conservation and Renewable Energy. September 19 2009. Retrieved September 9, 2009, from http:/csrwire.ca/article/1296/OSEA/19-9-08-Green-Energy-Act-Allianceendorses-Minister-Smithermans-directive.html

David Suzuki Foundation. (n.d.). Energy: Conservation and Efficiency. Retrieved September 13, 2009, from http:/www.davidsuzuki.org/Climate_Change/Energy/conservationefficiency.asp

David Suzuki Foundation. (1998). Canadian Solutions (Summary). Retrieved December 15, 2009 from http://www.davidsuzuki.org/files/cs_exec.pdf

David Suzuki Foundation. (2006a). Nuclear Power an Expensive Red Herring. March 17, 2006. Retrieved September 18, 2009 from

http://www.davidsuzuki.org/about_us/Dr_David_Suzuki/Article_Archives/weekly03170601.asp 
David Suzuki Foundation. (2009a). The David Suzuki Foundation: Home Page. Retrieved August 10, 2009, from http://www.davidsuzuki.org

David Suzuki Foundation. (2009b). Energy: Nuclear. Retrieved December 15, 2009, from http://www.davidsuzuki.org/Climate_Change/Energy/Nuclear.asp

DSF. (2006b). All Over the Map. Retrieved December 15, 2009 from

http://www.davidsuzuki.org/Publications/All_Over_the_Map_2006.asp

DSF. (n.d.). Low Impact Renewable Energy for a Clean Environment and Healthy Economy. Retrieved December 15, 2009 from http://www.davidsuzuki.org/Publications/Archives.asp

Edie News. (1999). Greenpeace USA Claims Victory as Gerber Baby Foods Go (Almost) GM Free. August 13, 1999. Retrieved September 9, 2009, from Edie News:

http: $/ /$ www.edie.net/news/news_story.asp?id $=1541$ \& channel $=0$

Energy Probe. (1997). Energy Probe's 1997 Accomplishments. Retrieved December 13, 2009 from http://energy.probeinternational.org/page-climate-change

Energy Probe. (n.d.). Climate Change. Retrieved February 9, 2010 from http://energy.probeinternational.org/page-climate-change

Energy Probe Senior Executive. (2009). Personal Communication. June 14, 2009.

Environmental Defense. (2007). Proposed Lake Simcoe Protection Act Applauded. Retrieved February 6, 2010 from

http://www.environmentaldefence.ca/pressroom/viewnews.php?id=130\&zoom_highlight=lakets imcoe

Environment Canada. (2009). Canada's Action on Climate Change. Retrieved February 4, 2010 from http://www.climatechange.gc.ca/default.asp?lang=En\&n=E18C8F2D-1/

Forester, J., \& Stitzel, D. (1989). Beyond Neutrality - the Possibilities of Activist Mediation in Public-Sector Conflicts. Negotiation Journal , 5(3):251-264.

Forest Stewardship Council. (n.d.). Procurement Policies. Retrieved August 12, 2009, from http://www.fsccanada.org/ProcurementPolicies.htm\#homedepot

Foster, D. (2009). The Great BPA Baby Panic of 2008: Financial Post Comment. The Financial Post, April 19, 2009.

G8. (2009). Agenda of Events, July 2009. Retrieved August 12, 2009, from

http://www.g8italia2009.it/G8/Home/G8-G8_Layout_locale-

1199882116809_Calendario.htm?m=LUG 
GBCA (Green Building Council Australia). (2006). Brisbane Council to Beat Kyoto Protocol Targets. Monday, December 18, 2006. Retrieved December 12, 2009 from http://www.gbca.org.au/news/brisbane-council-to-beat-kyoto-protocol-targets/1267.htm

GEAA (Green Energy Act Alliance). (2009). Expert Analysis of Bill 150 - The Green Energy and Green Economy Act, 2009 - Introductory Letter from the Green Energy Act Alliance Chair. March 16, 2009. Retrieved December 12, 2009 from

http://www.greenenergyact.ca/Page.asp?PageID $=122 \&$ ContentID $=1176 \&$ SiteNodeID $=235 \& B L$ ExpandID =

Glaser, B. and Strauss, A. (1967). The Discovery of Grounded Theory. New York, Aldine.

Gore, A. (2006). An Inconvenient Truth: The Planetary Emergency of Global Warming and What We Can Do About It. New York: Rodale.

Green Energy Coalition. (2008). Evidence in Support of a Greener Alternative to Ontario's Proposed Integrated Power System Plan. Retrieved February 11, 2010 from

http://pubs.pembina.org/reports/oeb-evidence-summary.pdf

Greenpeace Canada. (2008). Greenpeace Canada Annual Review 2008. Retrieved January 19, $2010 \mathrm{from}$ http://www.greenpeace.org/canada/en/documents-and-links/publications/annualreport-2008-en

Greenpeace Canada. (2009). Greenpeace Canada: Home Page. Retrieved August 10, 2009, from http://www.greenpeace.org/canada/en/

Gyorgy, A. \& Friends. (1979). No Nukes: Everyone's Guide to Nuclear Power. Black Rose Books, Montreal.

Habermas, J. (1977). Hannah Arendt's Communications Concept of Power. Social Research, 44(1):3-24.

Hamilton, T. (2009). \$26B Cost Killed Nuclear Bid. The Toronto Star, July 14, 2009.

Handy, F. (2001). Advocacy by Environmental Non-Profit Organisations: An Optimal Strategy for Addressing Environmental Problems? International Journal of Social Economics, 28(8):648666.

Heilman, S. (1976). Synagogue Life: A Study in Symbolic Interaction. Prentice Hall. Englewood Cliffs, New Jersey: Prentice Hall.

Hessing, M., Howlett, M., \& Summerville, T. (eds.). (2005). Canadian Natural Resource and Environmental Policy: Political Economy and Public Policy (Second Edition). Vancouver: UBC Press. 
ICBL. (2009). International Campaign to Ban Landmines: Ban History. Retrieved August 13, 2009, from http://www.icbl.org/index.php/icbl/Treaties/MBT/Ban-History

IICPH. (1999), Victims of the Nuclear Age. November 1, 1999. Retrieved January 19, 2010 from http://iicph.org/victims_of_the_nuclear_age

IICPH. (2009). Amazing Dr. Helen Caldicott. December 1, 2009. Retrieved January 19, 2010 from http://iicph.org/amazing-dr-helen-caldicott

Ikea. (2008). Ikea Sustainability Report. Retrieved August 12, 2009, from $\mathrm{http}: / / \mathrm{www} . i \mathrm{kea} . c o m / \mathrm{ms} / \mathrm{en}$ GB/about_ikea_new/about/read_our_materials/ikea_se_report_2008 .pdf

Independent Electricity System Operator. (2009). How Weather Affects Electricity Consumption. Retrieved August 12, 2009, from:

$\mathrm{http}: / / \mathrm{www}$. theweathernetwork.com/index.php?product=power\&pagecontent=poweront\#howele ctric

Inhaber, H. (1992a). Of LULUs, NIMBYs, and NIMTOOs. Public Interest , (107):52-64.

Inhaber, H. (1992b). Yard Sale. The Sciences, January/February 1992.

IPCC. (2007). IPCC Fourth Assessment Report: Climate Change 2007 (AR4). Retrieved on February 4, 2010 from

http://www.ipcc.ch/publications_and_data/publications_and_data_reports.htm

Jasanoff, S. (1997). NGOs and the Environment: From Knowledge to Action. Third World Quarterly, 18(3):579-594

Kingdon, J. (1984). Agendas, Alternatives, and Public Policies. London: Harper Collins.

Lincoln, Y. \& Guba, E. (1985). Naturalistic Inquiry. Newbury Park, CA: Sage

Linnerooth, J. (1984) The Political Processing of Uncertainty. Acta Psychologica 56:219-31.

Lovelock, B. (2002). Why it's Good to be Bad: The Role of Conflict in Contributing Towards Sustainable Tourism in Protected Areas. Journal of Sustainable Tourism, 10(1):5-30.

Lovelock, J. (2004). Nuclear Power is the Only Green Solution. May 14, 2004. Retrieved September 2, 2009, from http://www.ecolo.org/media/articles/articles.in.english/love-indep-2405-04.htm

Mann, M., \& Kump, L. (eds.) (2008). Dire Predictions: Understanding Global Warming (1st American Edition). New York: DK. 
Markandya, A. and Wilkinson, P. (2007). Electricity Generation and Health. The Lancet, 370(9591):979-990

Mason, J. (2002). Qualitative Researching, Second Edition. Sage Publications, London.

May, J. (1989). The Greenpeace Book of the Nuclear Age. Pantheon Books, New York.

McMullan, D. (1976). The Nuke Book: The Impact of Nuclear Development. Pollution Probe, Ottawa.

Mehta, M. (2005). Risky Business: Nuclear Power and Public Protest in Canada. Lanham, MD: Lexington Books.

Merriam, S. (1988). Case Study Research in Education. San Francisco: Jossey-Bass

Moore, P. (2006). Going Nuclear. The Washington Post, Sunday, April 16, 2006.

Nichols, M. (1997). CANDU Flawed. Retrieved December 13, 2009, from http://energy.probeinternational.org/nuclear-power/candu-flawed

Normore, J. (2009). Take the "DAVID SUZUKI NATURE CHALLENGE" We Need One Million Canadians! Retrieved August 13, 2009, from Facebook:

http:/www.facebook.com/search/?q=david+suzuki\&init=quick\#/group.php?gid=2243854875\&r ef $=$ search\&sid $=120805393.151723038 . .1$

Nuclear Energy Agency. (2006). Canada - National Laws and Regulations. Retrieved February 9, $2010 \mathrm{from} \mathrm{http://www.nea.fr/html/general/profiles/canada.htmlHlaw}$

NWMO. (n.d.). Be Involved. Retrieved February 9, 2010 from http://www.nwmo.ca/be_involved OCAA. (1999). Trading Our Health. Retrieved January 19, 2010 from http://www.cleanairalliance.org/node/454

OCAA. (2005). Candu Nuclear: A Canadian Edsel. Retrieved Dec 10, 2009, from http://www.cleanairalliance.org/files/active/0/candufs.pdf

OCAA. (2005a). Air Quality Issues Fact Sheet \#7 The Lambton Generating Station: Ontario's \#2 polluter. Retrieved December 10, 2009 from http://www.cleanairalliance.org/fs7

OCAA. (2009). Ontario Clean Air Alliance: Home Page. Retrieved August 10, 2009, from http://www.cleanairalliance.org

OCAA. (2009a). Ontario Clean Air Alliance: Province Still Mum on Cost of New Nuclear Plant . Retrieved August 11, 2009, from http://www.cleanairalliance.org/node/759 
OCAA. (2009b). Coal Phase-Out: A Major Climate Accomplishment Within Our Grasp.

Retrieved December 10,2009, from http://www.cleanairalliance.org/files/active/0/coalprogressfinal.pdf

OCAA. (2009c). Powerful Options. Retrieved January 19, 2010 from

http://www.cleanairalliance.org/files/active/0/replacingnuclear.pdf

Ontario Environmental Network (OEN). (n.d.). Ontario Environmental Directory. Retrieved January 17, 2009, from http://www.oen.ca/dir/list.php

OEN. (n.d.a). Environmental Bill of Rights. Retrieved February 2, 2010 from http://oen.ca/index.php?page=ebr

Ontario Regulation 276/06. (2006). Designation and Exemption of Integrated Power System Plan. June 12, 2006.

OPA. (2008). The Integrated Power System Plan for the Period 2008-2027. August 29, 2008. Retrieved September 2, 2009, from http://www.powerauthority.on.ca/ipsp/Storage/82/7763_B-11_updated_2008-09-04.pdf

OPA. (2009). Corporate Information: Integrated Power System Plan. Retrieved September 2, 2009, from://www.powerauthority.on.ca/IPSP/Page.asp?PageID=924\&SiteNodeID=320

Office of the Prime Minister. (2009). Backgrounder: Canada's Action on Climate Change. Retrieved February 4, 2010 from http://www.pm.gc.ca/eng/media.asp?id=3037

Patton, M. (1990). Qualitative Evaluation and Research Methods ( ${ }^{\text {nd }}$ ed.) Newbury Park, California: Sage

Pollution Probe. (2006). Comments on the Ontario Power Authority Supply Mix Advice Report. March 10, 2006. Retrieved January 19, 2010 from http://www.pollutionprobe.org/Reports/commentsenergy10-03-06.pdf

Pollution Probe. (2009). Energy Programme. Retrieved August 13, 2009, from http://www.pollutionprobe.org/whatwedo/Energy.htm

PowerWISE. (2009). PowerWISE: Home Page. Retrieved August 13, 2009, from http://www.powerwise.ca/

Sager, T. (1994). Communicative Planning Theory. England: Avebury.

Seattle.gov. (2007). The US Mayors' Climate Protection Agreement. Retrieved Dec 12, 2009 from http://www.seattle.gov/mayor/climate/default.htm\#what

Short, N. (1999). The Role of NGOs in the Ottawa Process to Ban Landmines. International Negotiation, 4(3):481-500. 
Silverman, D. (2000). Doing Qualitative Research: A Practical Handbook. London: SAGE Publications.

Solomon, L. (2009). The Dirty Truth. The National Post, February 20, 2009.

Solomon, L. (2009a). The Two Blows that Killed the Industry. Retrieved December 13, 2009, from http://energy probeinternational.org/nuclear-power/the-two-blows-killed-the-industry

Spears, T. (2009). Keeping Cool This Summer Should Be No Sweat. The Ottawa Citizen, July 2, 2009.

Spradley, J. (1979). The Ethnographic Interview. New York: Reinhart \& Winston.

Statistics Canada. (2005). Satellite account of non-profit institutions and volunteering . Retrieved September 2, 2009, from http://www.statcan.gc.ca/pub/13-015-x/2008000/ttab08-eng.htm

Stallen, P. and Koppock, R. (1987). About Risk Communication and Risky Communication. Risk Analysis, 7(4)

Stone, D. (2000). Non-Governmental Policy Transfer: The Strategies of Independent Policy Institutes. Governance, 13(1):45-62.

STORM. (n.d.). About STORM. Retrieved February 6, 2010 from http://www.stormcoalition.org/pages/about.html

Swedish Atomic Forum. (1982). Nuclear Sweden III. Stockholm, Sweden.

The Academy of Motion Picture Arts and Sciences. (2006). An Inconvenient Truth. Retrieved February 4, 2010 from http://awardsdatabase.oscars.org/ampas_awards/DisplayMain.jsp;jsessionid=65248DAE27DE42 78926E7972805DFC14?curTime $=1265302818357$

The Canadian Press. (2009). McGuinty Taking Time to Ponder Nuclear Plan. July 7, 2009. Retrieved August 10, 2009, from http://www.ctv.ca/servlet/ArticleNews/story/CTVNews/20090707/mcguinty_nuclear_090707/20 090707

The Edmonton Journal. (2009). Document Casts Cloud Over Carbon Capture. The Edmonton Journal, November 25, 2008.

The Nobel Foundation. (2007). The Nobel Peace Prize 2007. Retrieved February 4, 2010 fromhttp://nobelprize.org/nobel_prizes/peace/laureates/2007/index.html

The Ontario Ministry of the Environment. (2009). Climate Change: What Ontario is Doing. Retrieved February 4, 2010 from http://www.ene.gov.on.ca/en/air/climatechange/doing.php 
The Pembina Institute. (2009). Pembina: Home Page. Retrieved August 10, 2009, from http://www.pembina.org/

The Sydney Morning Herald. (2007). Australia Ratifies Kyoto Protocol. The Sydney Morning Herald, December 3, 2007.

Thompson, B. (1996). A Profile of Canadian NGOs. Retrieved August 13, 2009, from Canada's Coalition to End Global Poverty:

http://www.ccic.ca/f/archives/voluntary_sector_a_profile_of_canadian_ngos.pdf

Toronto Centre Provincial Liberal Association. (2009). Renewable Green Energy for Ontario. Retrieved February 2, 2010 from http://www.ontariogreenenergyact.ca/renew.html

Torgerson, D. (1985). Contextual Orientation in Policy Analysis. Policy Sciences, 18:241-61

Turnock, D. (2001). Environmental Problems and Policies in East Central Europe: A Changing Agenda. GeoJournal, 55(2-4):485.

UNFCCC. (2009). United Nations Framework Convention on Climate Change - the Kyoto Protocol. Retrieved August 10, 2009, from http://unfccc.int/kyoto_protocol/items/2830.php

Wapner, P. (2002). Horizontal Politics: Transnational Environmental Activism and Global Cultural Change. Global Environmental Politics , 2(2):37-62.

Wittner, L. (2009). Confronting the Bomb: A Short History of the World Nuclear Disarmament Movement. Stanford University Press, Stanford, California.

World Economic Forum. (2006). Trust in governments, corporations and global institutions continues to decline. Retrieved August 12, 2009, from

http://www2.weforum.org/site/homepublic.nsf/Content/Full+Survey_+Trust+in+Governments,+ Corporations + and + Global+Institutions + Continues+to+Decline.html

WNA. (2009a). Electricity Generation - Nuclear Power Reactors. Retrieved Dec 12, 2009, from http://www.world-nuclear.org/how/npreactors.html

WNA. (2009b). The Nuclear Renaissance. Retrieved August 23, 2009, from http://www.worldnuclear.org/info/inf104.htm 


\section{APPENDIX A: INTERVIEW GUIDES}

\section{Interview Guide 1}

Researcher: Thank you for agreeing to participate in this study. I estimate that this interview will take as little 20 minutes. Feel free to take as long as you wish to answer these questions, or to ask for clarification on anything. I would like to remind you that your responses will be confidential; your name will never be released. You may decline to answer any questions, and you may stop the interview at any time. This interview is being recorded. Do you have any questions before I begin the interview?

Note: Where appropriate, probes were used to encourage KIs to elaborate on their answers.

1) How would you define the term "pollution"?

2) Please name your number one concern for the environment today. Briefly, how would you choose to address it?

3) How would you rank climate change on the list of "most important environmental concerns"?

4) In your opinion, which method of electrical power generation is the most promising overall? Why?

5) Do you think that all energy option must be exploited to meet the needs of Canada's population? If not, which option must be used?

Researcher: The next five questions ask you to rate something. Please do so on a scale of 1 to 10,1 being the lowest, worst or least desirable rating, five being completely neutral, and 10 being the highest, best or most desirable rating.

6) How do you rate the nuclear industry's overall track record in terms of environmental impact?

7) How do you rate the nuclear industry's overall track record in terms of reliability?

8) How do you rate the nuclear industry's overall track record in terms of cost?

9) How do you rate the nuclear industry's overall track record in terms of efficiency?

10) How do you rate the nuclear industry's overall track record in terms of safety?

11) Can you briefly outline your organization's current position on nuclear power in Canada?

12) To the best of your knowledge, how does you organization's opinion on nuclear power today compare to your organization's opinion 15 years ago? Has it changed?

13) Do you think that your constituents/members/supporters support nuclear power or not? Do you think they would support nuclear power if nuclear power played an important part in fighting climate change?

14) If you were able to directly influence government policy, briefly explain what policies related to energy and the environment you would choose to influence.

15) Do you perceive a change in other ENGOs' stances on nuclear power? If so, how significant do you think that this shift has been: insignificant, moderately significant, very significant. 
16) Does your organization support any of the following:

a. Refurbishing or otherwise prolonging the lifespan of the current fleet of nuclear power plants;

b. Building new reactors for use in enhanced oil recovery in the oils sands;

c. Building new reactors at sites that already have nuclear reactors;

d. Deep geological disposal of nuclear waste;

e. New nuclear plants at sites that have never had a nuclear plant;

f. Transportation of nuclear waste from nuclear power plants to a separate, permanent disposal area.

The following questions will be asked if the participant currently does not support nuclear power:

17) What could persuade you that nuclear power was a useful part of Canada's climate change strategy into the future? For example, if some aspect of nuclear energy could be changed to make it attractive enough to use, what would that aspect be?

18) Has climate change or any other environmental problem made you consider supporting nuclear power to address that problem?

The following questions will be asked if the participant currently does support nuclear power:

19) What do you think is the most compelling reason to use nuclear power?

20) Do you consider climate change to be a important reason to use nuclear power?

Researcher: These three final questions are about you.

21) Which of the following describe your educational or work background? Choose all that apply:
a. Engineer
b. Activist
c. Scientist
d. Journalist
e. Businessperson
f. Public servant
g. Other (please specify)

22) What is your age range?
a. $18-25$
b. $26-35$
c. $36-45$
d. $46-55$
e. $56-65$
f. $66+$. 
23) What is your approximate salary?
a. $\$ 0-15000$
b. $15000-30000$
c. $30000-45000$
d. $45000-60000$
e. $60000-80000$
f. $80000-100000$
g. $>100000$
h. Volunteer, no salary

Researcher: If you would like to receive the results of this study I would be happy to send them to you. Thank you for your participation in this study. Do you have any final questions or comments?

\section{Interview Guide 2}

Researcher: The interview will take as little as 20 minutes, you can say as little or as much as you like. I would like to remind you that your responses will be confidential; your name will never be released. You can decline to answer questions if you wish, and can stop the interview at any time. This interview is being recorded. Do you have any questions before I begin?

1) How would you define the term "pollution"?

2) Please name your number one concern for the environment today.

3) In your opinion, what are the most promising technologies that could be used to generate electricity at the present time? Which technologies would you like to see invested in?

4) What kind of an energy supply mix should Canadians be pursuing?

5) Do you agree that the use of nuclear power in Canada is a controversial issue?

6) What do you consider to be the source of that controversy?

7) What do you consider to be the reason that some Canadian governments are willing to consider investing in nuclear power?

8) Can you briefly outline your organization's current position on nuclear power in Canada?

9) Has your organization's stance on nuclear power changed over the past 15 years? How so?

a. If so, has it changed because the nuclear industry has improved the technology?

10) Do your constituents/members/supporters support nuclear power? Do they believe that it is a useful tool for fighting climate change?

11) Are provincial and federal governments doing a satisfactory job of finding appropriate ways to conserve and supply electricity?

12) Do you know of any ENGO that has changed its stance and embraced nuclear power in the past 15 years?

13) Does your organization support any of the following:

a. New nuclear plants at sites that have never had a nuclear plant;

b. Building new reactors at sites that already have nuclear reactors;

c. Building new reactors for use in enhanced oil recovery in the oils sands;

d. Refurbishing existing nuclear capacity; 
e. Transportation of nuclear waste from nuclear power plants to a separate, permanent disposal area.

The following questions will be asked if the participant currently does not support nuclear power:

14) If some aspect of nuclear energy could be changed to make it attractive enough to use, what would that aspect be?

15) Has climate change or any other environmental problem made you consider supporting nuclear power to address that problem?

The following questions will be asked if the participant currently does support nuclear power:

16) What do you think is the most compelling reason to use nuclear power?

17) Do you consider climate change to be an important reason to use nuclear power?

Researcher: These three final questions are about you.

18) Which of the following describe your educational or work background? Choose all that apply:
a. Engineer
b. Activist
c. Scientist
d. Journalist
e. Businessperson
f. Public servant
g. Other (please specify)

19) What is your age range?
a. $18-25$
b. $26-35$
c. $36-45$
d. $46-55$
e. $56-65$
f. $66+$

20) Do you receive a salary from your organization?

Researcher: If you would like to receive the results of this study I would be happy to send them to you. Thank you for your participation in this study. Do you have any final questions or comments?

\section{Interview Guide 3 .}

The following interview guide was used to re-interview KIs 1 through 6 (the KIs that were originally part of the interview pre-testing).

1) What kind of energy supply mix should Canadians be pursuing or supporting?

2) Do you agree that nuclear power in Canada is a controversial issue?

a. What do you think is the source of that controversy? 
3) What do you consider to be the reason that some Canadian governments are willing to consider investing in nuclear energy?

4) Has your organization's stance on nuclear power changed over the past 15 years? How so?

a. If so, has it changed because the nuclear industry has improved its product?

5) Are provincial and federal governments doing a satisfactory job of finding appropriate ways to conserve and supply electricity?

6) Do you know of any ENGO that has changed its stance from anti-nuclear to pro-nuclear in the past 15 years? 


\section{APPENDiX B: EMAIL RECRUITMENT MESSAGe TEXT}

To [Potential Participant] at [Eligible ENGO],

I'm a Master's student at Ryerson University doing my thesis on NGO opinions towards nuclear power and electricity generation and I'd like to interview you or a member of your organization as part of my thesis research.

I would be interested in your opinions on various issues including climate change, alternative energy and nuclear power.

This study has been examined and endorsed by the Ryerson Ethics Board (REB). In order to protect you and other potential KIs, the entire process is completely confidential, your opinions and/or comments will never be attributed to you or your organization.

The interview itself will take as little as 20 minutes, and is done over the phone.

The nuclear industry and its supporters claim that nuclear power is a useful, effective, "green" solution for climate change and air pollution. This study intends to determine if the environmental NGO (ENGO) community agrees or disagrees with the nuclear industry's claims, and why. We feel this information will be useful for ENGOs, government officials and the public.

Please feel free to contact myself or my supervisor if you have any questions or concerns about the study. The contact information is below. If you know of anyone in your organization that would be willing to participate as well, or instead of yourself, please forward this message along to them.

Thank you for your consideration,

Jay Wilson (Student Researcher, Principal Investigator)

Email: \#\#\#\#\#\#\#@\#\#\#\#\#.ca

Prof. Ron Pushchak (Faculty Supervisor)

Email: pushchak@\#\#\#\#\#\#\#\#\#.ca

Work Phone: (416) 979-5000 x\#\# 


\section{APPENDIX C: ChangeS TO QUESTIONNAIRES}

The following notation will be used to clarify which question from which version of the questionnaire: two numerals will be used, separated by a dash. The first numeral will refer to the version of the questionnaire, and the second to the question itself. For example, references to question 11 on the pre-test version is noted as 1-11; for references to question 8 on the second version, the notation is $2-8$, and so on.

Question 1-1 was kept the same from the first to the second version. Question 1-2 was modified slightly, the second sentence ("Briefly, how would you choose to address it?") was removed. Question 1-3 was removed entirely. Question 1-4 was reworded in order to encourage respondents to consider technologies as they exist today, rather than as they might exist in the future. As well, Question 1-5 was removed entirely. Questions 1-6 to 1-10 were also removed; the wording and the numerical rating system used in these questions was deemed inappropriate. Question 1-11 became 2-8, but was otherwise unchanged. Question 1-12 became question 2-9, with a slight change; instead of asking how the informant's organization's position on nuclear power 15 years ago compares to today, it was put more simply in 2-9 ("Has your organization's stance on nuclear power changed over the past 15 years?"). As well, a prompt was added, but not used in the interviews. Question 1-13 became 2-10. Question 1-14 was changed significantly; it was reworded and became question 2-11, 2-11 is similar to 1-14 in that both inquire about effective policy, but 1-14 was deemed to be too narrow, while 2-11 got KIs to answer about how effective they felt government action was, and also had the effect of getting KIs to talk about what their organization would like to do in terms of policy. Question 1-15 was reworded and became 2-12. Question 1-16 was reordered, and the sub-question about whether 
they supported deep geological disposal was removed; $1-16$ became $2-13$ in the second version. Question 1-17 was reworded for clarity and became $2-14 ; 1-18,1-19,1-20,1-21$ and 1-22 became $2-15,2-16,2-17,2-18$ and 2-19, respectively, with no changes. The final question, 1-23, was changed to simply differentiate between those who received a salary and those who were volunteers in the second version; 1-23 became 2-20.

Some questions were simply added to the second version of the questionnaire. Question 2-4 was an elaboration on question 2-3. Questions 2-5 and 2-6 were not present in the first version of the questionnaire, but were added to address the controversy over nuclear power in Canada. Question 2-7 asked the informants to speculate on the reason that some governments were interested in nuclear power; something several informants in the pre-test worked into their responses unsolicited by the researcher. 